\title{
THE NEW LOOK IN MIITTARY JUSTICE
}

\author{
ROBINSON O. EVERETT*
}

A recent spate of widely publicized trials by court-martial has focused national attention on military justice. Some observers have concluded that it is still no more than "drumhead justice"1 and that "military justice is to justice as military music is to music." A similar appraisal underlies the Supreme Court's majority opinion in the landmark case of $O^{\prime}$ Callahan v. Parker, ${ }^{3}$ where Mr. Justice Douglas alludes to "so-called military justice," "the travesties of justice perpetrated" under the Uniform Code of Military Justice, ${ }^{5}$ and the circumstance that "courts-martial as an institution are singularly inept in dealing with the subtleties of constitutional law."

* Professor of Law, Duke University School of Law. A.B. 1947, LL.B. 1950, Harvard University; LL.M. 1959, Duke University.

1. See generally Conscience and Command (J. Finn ed. 1971); R. RivrIn, G.I. Rights and ARmy Justice: The Draftee's Guide to Milttary Life and Law (1970); Keefe, Drumhead Justice: A Look at Our Military Courts, Reader's Dig., Aug., 1951, at 39; Keefe \& Moskin, Codified Military Injustice, 35 CORNell L.Q. 151 (1949); Walsh, Can the Military Cope with Thirteen Books? 50 A.B.A.J. 67 (1964).

HEREINAFTER THE FOLLOWING CITATIONS WILL BE USED IN THIS ARTICLE:

Uniform Code of Military Justice arts. 1-140, 10 U.S.C. $\S \S 801-940$ (1970) [hereinafter cited as U.C.M.J.];

Manual For Courts-Marttal, United States (rev. ed. 1969), 34 Fed. Reg. 10,503 (1969) [hereinafter cited as MaNUAL];

1 Report of the TASK Force on the Administration of MIItARy JUstice IN THE ARMED FORCES (1972) [hereinafter cited as TASK FORCE REPORT];

U.S. Court of Military Appeals, Judge Advocates General \& General CounSEL OF THE DEP'T OF TRANSP., ANNUAL REPORT (1971) [hereinafter cited as 1971 ANNUAL REPORT];

Hearings on S. Res. 260 Before the Subcomm. on Constitutional Rights of the Senate Comm. on the Judiciary, 87th Cong., 2d Sess. (1962) [hereinafter cited as 1962 Hearings].

2. See R. Sherrill, Mitutary Justice Is to Justice as Mititary Music Is to Music (1969).

3. 395 U.S. 258 (1969). Sce note 7 infra and accompanying text.

4. Id. at 266 n.7.

5. Id. at 266. Congress originally enacted the Uniform Code of Military Justice in 1950. Act of May 5, 1950, ch. 169, $\$ 1,64$ Stat. 108 (codified at 10 U.S.C. $\$ \S$ 801-940 (1958)). This original Code was significantly amended in 1968. Act of Oct. 24,1968 , Pub. L. No. $90-632$, $\S 11-4,82$ Stat. 1335 , amending 10 U.S.C. $\$ \S 801$ 940 (1958) (codified at 10 U.S.C. $\$ \S 801-940$ (1970)). The U.C.M.J. constitutes the basic corpus juris of military law for all the armed forces. See notes 11-46 infra and accompanying text.

6. 395 U.S. at 265 . 
The majority's unflattering evaluation of military justice contributed substantially to its holding in O'Callahan that service personnel can only be tried by court-martial for "service-connected" offenses." Furthermore, if that evaluation remains the same, O'Callahan will probably be given a very sweeping interpretation, ${ }^{8}$ and the scope of civilian court review of courts-martial will expand. ${ }^{9}$ Similarly if Congress becomes convinced that military justice is of inferior quality, drastic legislative changes in the system will be forthcoming. ${ }^{10}$

This Article suggests, on the other hand, that the case against military justice has been exaggerated, that important reforms have already taken place, and that further major changes would be premature at this time. Indeed, in some respects military justice provides protections that are not available in civilian tribunals.

\section{Recent Legislative Reform-The Military Justice ACT of 1968}

When Congress enacted the Uniform Code of Military Justice in $1950,{ }^{11}$ it made important reforms and attempted-albeit without complete success ${ }^{12}$ - to institute the same system of military justice for

7. For discussions of this holding, see Relford v. Commandant, 401 U.S. 355,356 n.1 (1971) (citing authorities); Blumenfeld, Court-Martial Jurisdiction over CivilianType Crimes, 10 AM. CRIM. L. Rev. 51 (1971); Everett, O'Callahan v. Parker-Milestone or Millstone in Military Justice? 1969 DuKE L.J. 853; Nclson \& Westbrook, Court-Martial Jurisdiction over Servicemen for "Civilian" Offenses: An Analysis of O'Callahan v. Parker, 54 Mins. L. Rev. 1 (1969); Rice, O'Callahan v. Parker: Court-Martial Jurisdiction, "Service-Connection," Confusion, and the Serviceman, 51 MIITARY L. ReV. 41 (1971).

8. Conversely, a more favorable view of military justice by the Supreme Court may lead to a narrowing of the scope of the O'Callahan holding. See Everett, supra note 7.

9. For commentary on civilian court review of courts-martial, see Bishop, Civilian Judges and Military Justice: Collateral Review of Court-Martial Convictions, 61 Colum. L. Rev. 40 (1961); Everett, Collateral Attack on Court-Martial Convictions, 11 AIr Force Judge Advocate General L. Rev. 399 (1969); Sherman, Judicial Review of Military Determinations and the Exhaustion of Remedies Requirement, 55 VA. L. Rev. 483 (1969); Weckstein, Federal Court Review of Courts-Martial Proceedings: A Delicate Balance of Individual Rights and Military Responsibilities, 54 MuITARY L. REV. 1 (1971).

10. As to proposals for legislative changes, see Bayh, The Military Justice Act of 1971: The Need for Legislative Reform, 10 AM. CRrM. L. REv. 9 (1971); Sherman, Congressional Proposals for Reform of Military Law, 10 AM. CRIM. L. Rev. 25 (1971).

11. See note 5 supra.

12. Congress considered that, as to certain matters, the secretaries of the various military departments should remain free to promulgate their own directives. See, e.g., U.C.M.J. arts. 14 (delivery of offenders to civil authorities), 15 (nonjudicial punishment), 58 (execution of confinement), 65 (disposition of certain records of trial), 10 U.S.C. $\$ \S 814-15,858,865$ (1970). Illustrative of the diversity in policy among 
all the armed services. Among its most significant achievements, the Uniform Code created an all-civilian Court of Military Appeals to review serious cases, ${ }^{13}$ provided for the inclusion of legally qualified law officers in general courts-martial, ${ }^{14}$ commanded that legally qualified counsel be furnished to accused in general courts-martial. ${ }^{15}$ and required a warning to suspects of their right to remain silent. ${ }^{18}$ Despite not infrequent complaints, only minor changes were made in the $\operatorname{Code}^{17}$ until

the armed services are: (1) extensive plea-bargaining in the Army, Navy, and Marine Corps, but a prohibition thereof in the Air Force; (2) use of a trial judiciary in the Army, Navy, and Marine Corps, but not in the Air Force; (3) adjudging of bad couduct discharges by special courts-martial in the Navy, Marine Corps, and Air Force, but not in the Army; (4) providing lawyers to defend and prosecute a substantial percentage of special courts-martial in the Air Force, but not in the other services. As to the last three of these four matters, there is now uniformity as a result of the Military Justice Act of 1968.

13. Id. art. 67, 10 U.S.C. $\$ 867$. The Court of Military Appeals can only review cases which have been reviewed by a Court of Military Review-until 1969 known as a Board of Review. Id. art. 67(b), 10 U.S.C. $\$ 867(\mathrm{~b})$. The Courts of Military Review must review trials by court-martial which involve an approved sentence of death, dismissal, dishonorable or bad conduct discharge, or confinement for one year or more, and cases in which the sentence, as approved, affects a general or flag officer. Id. art. 66, 10 U.S.C. $\$ 866$. Also, the Judge Advocate General may refer other records of trial by general court-martial to a Court of Military Review. Id. art. 69, 10 U.S.C. $\$ 869$.

14. Act of May 5, 1950, ch. 169, $\$ 1$ (art. 26), 64 Stat. 117. See notes 21-22 infra and accoinpanying text. The general court-martial, usually convened for only the most serious types of offenses, is empowered to adjudge "any punishment not forbidden by [the Uniform Code], including the penalty of death when specifically authorized by [the Uniform Code]." U.C.M.J. art. 18, 10 U.S.C. $\& 818$ (1970). The special court-martial, convened for less serious offenses or for cases where a summary court-martial has been rejected by the accused, may adjudge sentences including bad conduct discharge, confinement of up to six months, and forfeiture of pay, not exceeding two thirds of monthly pay, for up to six months. Id. art. 19, 10 U.S.C. \& 819. The summary court-martial, convened for still lesser offenses or for cases where nonjudicial punishment has been waived, may impose a sentence of up to thirty days' confinement at hard labor and partial forfeiture of pay for up to one month. Id. art. 20, 10 U.S.C. $\$ 820$. Finally, commanding officers are authorized to impose such disciplinary measures as restriction to base or arrest in quarters under the Uniform Code's nonjudicial punishment procedures. Id. art. 15, 10 U.S.C. $\& 815$.

15. Act of May 5, 1950, ch. 169, \& 1 (art. 27), 64 Stat. 117.

16. U.C.M.J. art. 31,10 U.S.C. $\$ 831$ (1970).

17. Probably the most important change was the expansion in 1962 of a commander's authority to unpose nonjudicial punishment under article 15 of the Uniform Code. Act of Sept. 7, 1962, Pub. L. No. 87-648, \& 1 (art. 15), 76 Stat. 447. See also U.C.M.J. art. 58(a), 10 U.S.C. $\$ 858$ (a) (1970), which provides for certain automatic reductions in enlisted grade upon approval by the convening authority of a sentence including a punitive discharge, confinement, or hard labor without confinement. Act of July 12, 1960, Pub. L. No. 86-633, § 1(1) (art. 58(a)), 74 Stat. 468. In 1961 a specific punitive article was enacted to prohibit certain worthless check offenses. Act of Oct. 4, 1961, Pub. L. No. 87-385, \$1(1) (art. 123(a)), 75 Stat. 814. 
enactment of the Military Justice Act of $1968 .{ }^{18}$ This legislation, which was enacted prior to the O'Callahan decision but which did not take effect until several months thereafter, ${ }^{10}$ resulted chiefly from the efforts of Senator Sam J. Ervin, Jr., whose Subcommittee on Constitutional Rights had conducted hearings on military justice in 1962 and 1966 and had recommended extensive changes. ${ }^{20}$

Perhaps the greatest cliange accomplished by the Military Justice Act of 1968 was its creation of the post of military judge. Even prior to the Uniform Code, Army and Air Force general courts-martial had a law member, who was legally trained and who alone made rulings of law during the trial. Additionally, the law member deliberated on guilt and sentence with the other court members. The Code required that each general court-martial have a law officer, who was to be an attorney certified by the Judge Advocate General of his armed force as qualified for such duty. ${ }^{21}$ This law officer sat apart from the court members, ruled on interlocutory matters, instructed the members of the court concerning applicable law, but did not join in their deliberations. However, unlike a civilian judge, his rulings on a motion for a finding of not guilty were not final and could be overturned by the court members-the jury; nor could he rule finally on challenges for cause to members of the court-martial. ${ }^{22}$

Under the Code there was no requirement that service as law officer be a primary duty; and often a law officer might serve in that capacity only a few times each year. Moreover, the law officer might

18. Act of Oct. 24, 1968, Pub. L. No. 90-632, §§ 1-4, 82 Stat. 1335.

19. The effective date was August 1,1969, with respect to most of the provisions of the Act. Id. \& 4, 82 Stat. 1343. That passage of the Act had not been foreseen by the armed services is attested to by their promulgation, earlier in 1968, of a new Manual for Courts-Martial, which almost immediately was made obsolete by this legislation. The Manual for Courts-Martial, United States (1969) was promulgated by President Johnson and took effect January 1, 1969. It was superseded on August 1, 1969, by the Manual for Courts-Martial, United States (rev. ed. 1969), which was prescribed by an executive order of President Nixon in order to conform to the changes effected by the Military Justice Act of 1968. Exec. Order No. 11,476, 3 C.F.R. 132 (1969 Compilation).

20. See Subcomm. on Constitutional Rights of the Senate Comm. on the Judiciarx, 88Th CoNg., 1St Sess., Summary-Report of Hearings on ConstituTIONAL Rights of Military Personnel (1963); 1962 Hearings; Joint Hearings Before the Subcomm. on Constitutional Rights of the Senate Comm. on the Judiciary and a Special Subcomm. of the Senate Comm. on Armed Services, 89th Cong., 2d Sess., pt. 1 (1966).

21. Act of May 5, 1950, ch. 169, § 1 (art. 26(a)), 64 Stat. 117, as amended, 10 U.S.C. $\$ 826$ (a) (1970).

22. See Act of May 5, 1950, ch. 169, $\$ 1$ (art. 51), 64 Stat. 124, as amended, 10 U.S.C. $\$ 851$ (1970). 
be a lawyer on the staff of the commander who, as convening authority, had referred the charges to the court for trial. Thus, there existed a real possibility of command influence.

Cognizant of these problems, the Army on its own initiative created a field judiciary consisting of officers certified as law officers whose primary duty was to serve on general courts-martial. The members of this field judiciary were not under the command of local commanders. They were assigned from Washington, and their efficiency reports were prepared in the Office of the Judge Advocate General of the Army. ${ }^{23}$ The Navy and Marine Corps soon created similar field judiciaries. The Air Force, on the other hand, contended that it did not need such a system, which, in its opinion, would create personnel problems without improving the quality of justice.

Unimpressed by the Air Force position, Congress required in the 1968 Act that each armed force have a trial judiciary for general courts-martial. To enhance the prestige of the law officer, his title was changed to military judge ${ }^{24}$ and his powers were enhanced significantly. Specifically, the military judge was authorized to rule finally on challenges, motions for findings of not guilty, all questions of law, and any interlocutory question "other than the factual issue of mental responsibility of the accused." ${ }^{25}$ As the Act has been implemented, each service now has a trial judiciary of officers whose primary duty is service as military judges of general courts-martial, who are not subject to any local commander in the field, and whose efficiency reports are prepared in the Office of the Judge Advocate General. ${ }^{26}$

Moreover, the Act now provides that a special court-martial may have a military judge and that no bad conduct discharge may be adjudged by a special court-martial unless a military judge has been detailed to the trial, except in a case where a military judge could not be detailed because of physical conditions or military exigencies. ${ }^{27}$ Additionally, each armed service may have a number of other commissioned officers who are lawyers and who have been certified as being qualified to serve as military judge for special courts-martial. For these officers,

23. See 1962 Hearings 838-40, 868, 904-05, 922-23; Karlen, How the Army Trains Its Judges, 34 U. Mo. KAN. CITY L. Rev. 271 (1966); Wiener, The Army's Field Judiciary System: A Notable Advance, 46 A.B.A.J. 1178 (1960).

24. U.C.M.J. art. 26, 10 U.S.C. \& 826 (1970).

25. Id. art. 51(b), 10 U.S.C. $\$ 851(\mathrm{~b})$.

26. See id. art. 26(c), 10 U.S.C. $\$ 826(\mathrm{c})$.

27. Id. art. 19, 10 U.S.C. $\& 819$. Under these circumstances, "the convening authority shall make a detailed written statement, to be appended to the record, stating the reason or reasons a military judge could not be detailed." $I d$. 
however, service as military judge need not be a primary duty. ${ }^{28}$ Also, they may be subject to commanders in the field-including a commander who convenes or reviews the special courts-martial on which they sit as military judge.

Responding to allegations of command influence on defense counsel and court members, the Act broadens previous prohibitions against these extrajudicial pressures on the personnel of courts-martial. ${ }^{20}$ Thus, a defense counsel may not be given a lower efficiency rating because of the zeal with which he represented an accused before a courtInartial; nor may performance of duty as a court nember be considered in preparing any report or document to be used in determining promotions, assignments, or retention on active duty. The pretrial instruction that a commander or his staff judge advocate may provide to court members is also sharply curtailed. ${ }^{30}$

Beyond its extensive revision in the area of the powers and independence of judicial personnel, the 1968 Act provided further reform in the area of the procedural rights of the accused. Of particular significance are the greater flexibility allowed the military defendant in selecting the type of tribunal in which he is to be heard and the expanded provision for counsel. In a federal district court, a defendant may waive trial by jury if the Government and the court are willing. ${ }^{31}$ The Uniform Code, on the other hand, did not authorize an accused to waive trial by the members of a general court-martial and be tried by the law officer-the judge-of that court. ${ }^{32}$ The Military Justice Act of 1968 now provides this right to an accused, contingent upon

28. See id. art. 26(a)-(c), 10 U.S.C. \& 826(a)-(c).

29. See id. art. 37,10 U.S.C. $\$ 837$.

30. Id. art. 37(a), 10 U.S.C. $\$ 837$ (a). Under the 1951 Manual for CourtsMartial, a convening authority could give

general instruction to the personnel of a court-martial which he has appointed, preferably before any cases have been referred to the court for trial .... Such instruction may relate to the rules of evidence, burden of proof, and presumption of innocence, and may include information as to the state of discipline in the coinmand, as to prevalence of offenses which have impaired efficiency and discipline, and of command measures which have been taken to prevent offenses. MANUAL FOR COURTS-MARTIAL, UNITED STATES $\int 38$ (1951).

Pretrial instruction pursuant to this paragraph was upheld in United States v. Danzine, 12 U.S.C.M.A. 350, 30 C.M.R. 350 (1961). Because of complaints about giving pretrial instructions to court-martial inembers, the Army discontinued the practice in 1962. See 1962 Hearings 869.

31. Singer v. United States, 380 U.S. 24 (1965); Patton v. United States, 281 U.S. $276(1930)$.

32. Under the original Uniform Code there was no provision for a law officer in a special court-martial, and so only in general courts-martial was a waiver of trial by the court-martial members even a theoretical possibility. 
the consent of the military judge but not requiring the Government's approval. $^{33}$ The waiver is permitted both for general courts-martial and for special courts-martial to which a military judge has been detailed. In practice, this right has been widely utilized by accused and their counsel; a very high percentage of cases are now tried by the military judge alone. ${ }^{34}$

Although the Uniform Code required that legally qualified counsel be appointed to represent the accused in a general court-martial, there was no similar requirement for special courts-martial, which may adjudge sentences including bad conduct discharge, six months' confinement at hard labor, and partial forfeiture of pay for six months. ${ }^{35}$ The Military Justice Act of 1968 now prohibits a special court-martial from adjudging a bad conduct discharge unless legally qualified counsel has been appointed to represent the accused ${ }^{36}$ Furthermore, it requires that such counsel be provided in other special courts-martial unless precluded by physicial conditions or military exigencies. ${ }^{37}$

The Uniform Code permitted an accused to object to trial by summary court-martial if he had not been offered nonjudicial punishment under article 15 of the Code. ${ }^{38}$ If, however, nonjudicial punishment had been offered him and he had declined it, this objection was not available. Thus, an enlisted man might be offered nonjudicial punishment for a minor offense, decline to accept it, and then be subjected to trial by summary court-martial-where no counsel was furnished him $^{39}$ but where he might receive a sentence of up to thirty days' confinement at hard labor and forfeiture of pay for the same period. The 1968 Act now authorizes him to object to trial by summary court-martial regardless of any prior offer of nonjudicial punishment. ${ }^{40}$

33. U.C.M.J. art. 16(1)(B), (2)(C), 10 U.S.C. $\S \S 816(1)(B),(2)(C)$ (1970).

34. For 1971, the Judge Advocate General of the Army reports:

Trials by military judge alone continued at a high percentage throughout the year. About 95 percent of special courts-martial were tried by judge alone, while the figure for general courts-martial was about 84 percent. These trials resulted in a tremendous savings of line officer hours during the year. 1971 ANNUAL REPORT 20.

35. U.C.M.J. art. 19, 10 U.S.C. $\$ 819$ (1958), as amended, 10 U.S.C. $\$ 819$ (1970).

36. U.C.M.J. art. 19, 10 U.S.C. $\$ 819$ (1970).

37. Id. art. 27 (c)(1), 10 U.S.C. $\$ 827($ c)(1). In this event "the convening atrthority shall make a detailed written statement, to be appended to the record, stating why counsel with such qualifications could not be obtained . . . ." Id.

38. Act of May 5, 1950, ch. 169, 1 (art. 20), 64 Stat. 114. See note 14 supra for a brief summary of the relative punitive capacities of the basic military tribunals.

39. Two recent federal district court cases, however, have squarely held that the accused in a summary court-martial is constitutionally entitled to representation by counsel. See note 154 infra and accompanying text.

40. U.C.M.J. art. 20,10 U.S.C. $\$ 820$ (1970). 
In that event the charges may be referred to a special or general courtmartial, where the accused will now normally be represented by a qualified counsel and tried before a military judge. However, even under the Act, it appears that if the accused is then convicted by the special or general court-martial, his punishment will not necessarily be limited to that which could have been imposed by a summary court-martial. ${ }^{41}$

Post-conviction rights of the accused were also expanded by the Military Justice Act of 1968 . The period for submitting a petition for a new trial was extended from one to two years. ${ }^{42}$ The Boards of Review were redesignated as Courts of Military Review; their members were termed appellate military judges; and these tribunals were subjected to additional procedural safeguards. ${ }^{43}$ For example, an element of possible command influence was removed from the procedure by the termination of the practice whereby the senior member of the Board prepared fitness reports on the junior members' performance on the Board for submission to military superiors. A procedure was made available for deferring service of a sentence to confinement pending completion of appellate review. ${ }^{44}$ For cases not reviewed by a Court of Military Review, the Judge Advocate General was granted broad authority to review. ${ }^{45}$

In addition to providing additional protections for the rights of the accused, the Military Justice Act of 1968 significantly streamlined the functioning of military justice-thereby pleasing the armed services as well as the proponents of reform. Indeed, this streamlining was probably a major quid pro quo for the procedural safeguards which Senator Ervin and others obtained in this legislation for military accused. The Act's provision for waiver of trial by the full military jury in favor of trial by military judge alone-an option which has been extensively

41. At one time it might have been argued that to allow a special or general courtmartial to impose upon an accnsed a punishment more severe than he might have received from a summary court-martial would have a chilling effect on his statutory right to object to trial by summary court-martial. See, e.g., Jackson v. United States, 390 U.S. 570 (1968). However, in light of the recent Supreme Court decision in Colten v. Kentucky, 407 U.S. 104 (1972), which allowed a more severe sentence after an appeal and de novo trial, it seems likely that the accused who has objected to trial by summary court-martial could be held subject to a sentence more severe than a summary court-martial might have imposed.

42. U.C.M.J. art. 73, 10 U.S.C. $\$ 873$ (1970).

43. Id. art. $66(\mathrm{~g}), 10$ U.S.C. $\$ 866(\mathrm{~g})$.

44. Id. art. 57(d), 10 U.S.C. $\$ 857$ (d). Service of confinement may be deferred in the sole discretion of the convening authority or, if the accused is no longer under his jurisdiction, the officer exercising general court-martial jurisdiction over the command to which the accused is currently assigned.

45. See id. art. 69, 10 U.S.C. $\$ 869$; Everett, supra note 9, at 400. 
utilized $^{46}$ - has been a major factor in expediting military justice and improving its efficiency. Moreover, the pre-1968 Uniform Code inade no provision for a pretrial session to dispose of procedural and interlocutory questions, with the result that impatient court-martial members often waited for hours while the law officer and counsel dealt with matters which in the federal district courts would have been disposed of long before trial. The 1968 Act now authorizes such pretrial sessions and thereby allows the military judge to consider motions to suppress evidence, to receive the accused's plea, and to dispose of similar procedural matters before the full court-martial convenes. ${ }^{47}$ The result is to render the court-martial a more efficient instrument of military justice.

\section{O'Callahan v. Parker}

In June 1969-after enactment of the Military Justice Act of 1968 but prior to its effective date ${ }^{48}$ - the Supreine Court substantially constricted the scope of military jurisdiction. O'Callahan v. Parker held that, at least within the Umited States in time of peace, courtsmartial could try only those offenses that were "service-connected." 49 The criteria for service-connection were left somewhat imprecise, although a subsequent Supreme Court decision made it clear that conduct occurring on a military installation would qualify as service-connected. ${ }^{50}$

The inajority opinion in $O^{\prime}$ Callahan emphasized that courts-martial do not utilize grand jury indictment or trial by jury. Since petty offenses do not require grand jury indictment or trial by jury, it would seem arguable that they are not subject to the requirement of serviceconnection-as the Court of Military Appeals has since ruled. ${ }^{51}$ Similarly, to the extent that the result in $O^{\prime}$ Callahan hinges solely on the military court's demal of procedural safeguards available in the civilian courts, the argument is persuasive that the decision lacks extraterritorial effect. ${ }^{52}$ Since a large number of offenses committed by servicemen overseas "are not cognizable in any civil court in the Umited States,"53

46. See note 34 supra and accompanying text.

47. U.C.M.J. art. 39(a), 10 U.S.C. $\$ 839$ (a) (1970).

48. The effective date was August 1, 1969. See note 19 supra.

49. 395 U.S. 258 (1969). See authorities cited note 7 supra.

50. Relford v. Commandant, 401 U.S. 355 (1971).

51. United States v. Sharkey, 19 U.S.C.M.A. 26, 41 C.M.R. 26 (1969); Blumenfeld, supra note 7, at 71; Everett, supra note 7, at 893 \& n.178.

52. The Court of Military Appeals has ruled that $O^{\prime}$ Callahan does not apply to offenses committed overseas. Umited States v. Keaton, 19 U.S.C.M.A. 64, 41 C.M.R. 64 (1969).

53. Id. at 67, 41 C.M.R. at 67. 
the accused serviceman's only alternative to military trial would be trial in the courts of the host country-where grand jury indictment and trial by jury would rarely be heard of, much less practiced.

In holding the right to trial by jury applicable to state prosecutions, the Supreme Court ruled only prospectively. ${ }^{54}$ Therefore, insofar as O'Callahan is grounded on the accused's right to jury trial, parallel reasoning would suggest only prospective application of its holding as well. The Court of Military Appeals has already so held, ${ }^{55}$ although the circuit courts have gone both ways on the retroactivity issue. ${ }^{B B}$ Furthermore, if the rationale of $O^{\prime}$ Callahan goes only to the imperfect exercise of otherwise valid jurisdiction-rather than to a lack of congressional power, through the armed services, to prosecute certain conduct - then a serviceman's nonservice-connected acts could be made subject to federal prosecution in a tribunal that offered grand jury imdictment and trial by jury.

However, the opinion in $O^{\prime}$ Callahan also relied on the majority's interpretation of article I, section 8, clause 14 of the United States Constitution, which gives Congress power "to make Rules for the Government and Regulation of the land and naval Forces." There is, at the very least, a strong intimation that this constitutional provision falls short of giving Congress the power to prohibit conduct on the part of military personnel that is not service-connected. In that event, the argument for both the extraterritoriality and the retroactivity of $\mathrm{O}^{\prime} \mathrm{Cal}$ lahan is strengthened, since the very constitutional underpinnings of the power to regulate nonmilitary conduct would be absent. Moreover, the conclusion could be logically drawn that, even if grand jury indictment and trial by jury were provided, federal jurisdiction cannot be created to enable the armed services rather than the normal prosecutorial agencies to prosecute a serviceman for conduct that is not serviceconnected.

Regardless of the soundness of its rationale and result, $O^{\prime}$ Callahan has helped to create a new look in military justice. ${ }^{57}$ For one thing, the potential caseload of courts-martial has been diminished by elimi-

54. De Stafano v. Woods, 392 U.S. 631 (1968). See Everett, supra note 7, at 888-89.

55. Mercer v. Dillon, 19 U.S.C.M.A. 264, 41 C.M.R. 264 (1970), holds that $O$ 'Callahan is not retroactive.

56. Compare Gosa v. Mayden, 450 F.2d 753 (5th Cir. 1971), cert. granted, 407 U.S. 920 (1972) (O'Callahan applies prospectively only) with United States $e x$ rel. Flemings v. Chafee, 458 F.2d 544 (2d Cir.), cert. granted sub nom. Warner v. Flemings, 407 U.S. 919 (1972) (O'Callahan applies retroactively). The Supreme Court has heard oral argument in both cases, 41 U.S.L.W. 3326 (U.S. Dec. 4, 1972); and a decision is pending as this article goes to press.

57. For varying views on $O^{\prime}$ Callahan, see authorities cited note 7 supra. 
nation of all offenses that are not service-connected-at least within the United States. Secondly, the composition of the caseload has been altered. Civil-type offenses, such as murder, rape, and larceny, can no longer be tried by court-martial unless they occurred on a military post or involved a military victim. Likewise, the occasion for conflict between military and civilian authorities in determining which shall prosecute such offenses has been reduced; generally, only the civilian authorities will have jurisdiction to prosecute. Thirdly, there has been injected into military trials an issue that was not previously encountered-namely, the service-connection of the offense. ${ }^{58}$ As a result, a new avenue has become available to attack court-martial convictions collaterally in the civilian courts, since absence of service-connection will deprive the court-1nartial of its jurisdiction. ${ }^{59}$

Although one reading of $O^{\prime}$ Callahan would permit Congress to authorize the prosecution of nonservice-connected offenses in federal district courts, no effort to do so seems likely. Thus, except for petty offenses, a military commander cannot take action against conduct which is not service-connected. Moreover, if he orders his personnel to refrain from conduct which is not service-connected, the legality of the order would seem highly questionable. In short, nihtary justice since $O^{\prime} C a l l a h a n$ does not give commanders the same breadth of control over their subordinates which they previously possessed.

Perluaps the opinion in $O^{\prime}$ Callahan has had some tendency to alleviate pressure for change within military justice. The occasions for military justice to inupinge on servieemen, their families, and friends were lessened. The instances were fewer when a civil-type offense, familiar to state and federal civil courts, would be tried by the unfamiliar procedures of courts-martial. On the other hand, the vehemence of the criticisn of military justice in O'Callahan may have given added impetus to pressures for change froin sources external to the military.

\section{JUdiCIAL Vindication OF THE CONSTITUTIONAL RIGHTS OF SERVICEMEN}

Until 1953 - two years after the Uniform Code of Military Justice took effect-there had been no clear Supreine Court decision or legis-

58. Prior to O'Callahan, the word "service-connection" had never been used by the Court of Military Appeals and had appeared in only one Board of Review opinion. Congress had been concerned with service-connection chiefly in the area of retirement benefits and disability pay. See Everett, supra note 7, at 870 .

59. In view of the exhaustion of remedies requirement, the question arises whether absence of service-connection can be asserted in a civil court prior to trial by court- 
lative pronouncement that military personnel were entitled to the protections of the Constitution. Moreover, although court-martial convictions had sometimes been attacked collaterally in the federal district courts, the sole test for such attacks had apparently been the jurisdiction of the court-martial. ${ }^{60}$ In that respect, albeit in a different context, the Supreme Court had recognized that constitutional violations could sometimes affect a court's jurisdiction to proceed with a trial. ${ }^{61}$

In Burns v. Wilson ${ }^{62}$ a court-martial conviction for murder and rape and the accompanying death sentence were collaterally attacked by means of a petition for habeas corpus in a federal district court. Chief Justice Vinson, writing for himself and three other Justices, noted that the "military courts, like the state courts, have the same responsibilities as do the federal courts to protect a person from a violation of his constitutional rights." ${ }^{\text {"63 }}$ However, he went on to deny the application for habeas corpus since the military authorities had dealt fully and fairly with the petitioners' allegations that they had been demed due process in their trial. Although the Vinson opinion did not command a full majority, examination of the dissents makes clear that the Supreme Court had authorized the federal civil courts to undertake collateral review of court-martial action if military authorities failed to give full consideration to constitutional claims made by the accused. ${ }^{64}$ Thus, Burns $v$. Wilson gave tacit recognition that military personnel have some constitutional rights in the administration of military justice and also provided some means of vindicating those rights.

In United States v. Augenblick ${ }^{65}$ the Supreme Court in 1969 refused to allow the extension of collateral review to mclude errors not

martial and appellate review within the military establishment. See id. at 894-95. Cf. Parisi v. Davidson, 405 U.S. 34 (1972); Noyd v. Bond, 395 U.S. 683 (1969). 60. See Hiatt v. Brown, 339 U.S. 103, 111 (1950); In re Grimley, 137 U.S. 147, $150(1890)$.

61. See, e.g., Johnson v. Zerbst, 304 U.S. 458 (1938).

62. 346 U.S. 137 (1953).

63. Id. at 142 .

64. In dissent Justices Douglas and Black contended that the accused were entitled to a judicial hearing on the claims that their confessions were involuntary. However, they conceded that if "the military agency has fairly and conscientiously applied the standards of due process formulated by this Court, . . . a rehash of the same facts by a federal court would not advance the cause of justice." Id. at 154 (dissenting opinion). Recently a court of appeals ruled that federal courts should apply the same standard to review of court-martial convictions that is utilized in review of state court convictions on habeas corpus and should not be precluded from review of constitutional claims by reason of prior full and fair consideration of those clains by military authorities. Kauffman v. Seeretary of the Air Force, 415 F.2d 991 (D.C. Cir. 1969). 65. 393 U.S. 348 (1969). 
deemed of constitutional proportions. That same year, in Noyd $v$. Bond, ${ }^{\circ B}$ a requirement of exhaustion of remedies was upheld by the Supreme Court. As a result, the military accused cannot seek review in the federal civil courts until their remedies within the military system have been exhausted.

Despite the uncertainty in other tribunals, the Court of Military Appeals has long since embraced the view "that the protections in the Bill of Rights, except those which are expressly or by necessary implication, inapplicable, are available to meinbers of our armed forces." ${ }^{77}$ More recently it has recognized the availability of extraordinary remedies, such as the writ of error corain nobis, within the system of military justice itself, ${ }^{68}$ thus providing an additional weapon for protection of the constitutional rights of service personnel. Just as has been true in some states which have developed post-conviction procedures for collateral review, one inducement for approving extraordinary remedies in military justice was probably to insulate court-martial convictions more completely from civilian court review. In any event, the result has been to provide military lawyers with an array of extraordinary writs and renedies similar to those utilized in the civilian courts.

\section{InNovation by the ARMed Services}

Although the new look in military justice owes much to Congress and the courts, the armed services have in several instances displayed notable innovativeness in changing the system. For example, the Army took the initiative in removing law officers from the control of commanders in the field and placing them in a field judiciary responsible to the Judge Advocate General. ${ }^{69}$ The Air Force lias undertaken, and recently extended, a pilot program whereunder the military judges for special courts-inartial are also placed in the trial judiciary and insulated from the nonlegal cham of command. ${ }^{70}$ The Air Force has

66. 395 U.S. 683 (1969).

67. United States v. Jacoby, 11 U.S.C.M.A. 428, 430-31, 29 C.M.R. 244, 246 (1960). See also United States v. Tempia, 16 U.S.C.M.A. 629, 37 C.M.R. 249 (1967).

68. See United States v. Snyder, 18 U.S.C.M.A. 480, 40 C.M.R. 192 (1969); United States v. Bevilacqua, 18 U.S.C.M.A. 10, 39 C.M.R. 10 (1968). See also Everett, supra note 9.

59. See note 23 supra and accompanying text.

70. On June 1, 1971, the pilot project for the Air Force Judiciary Trial Division officially began its test period. This project, which was discussed in the January 1, 1970-December 31, 1970 report, is one in which some 15 judge advocates were assigned as fulltime trial and defense counsel and special court-nıartial military judges within geographical districts within the $2 \mathrm{~d}$ Circuit of the eastern U.S. Judiciary Region. They work out of offices at Maxwell AFB, Ala., Keesler AFB, Miss., MacDill AFB, Fla., and Shaw AFB, S.C. All report directly to The Judge Advocate General rather than 
also begun to establish a full-time trial and defense bar for courts-martial-composed of counsel who are not subject to assignment or evaluation by unit commanders. In a similar vein, the Navy has developed law centers where legal activities are centralized and more thoroughly isolated from the possible influence of general command headquarters.

The Army has provided for military magistrates authorized to issue search warrants and to order release from pretrial confinement, ${ }^{71}$ lessening somewhat the scope of possible abuse of command discretion in those areas. The Army has also formalized the negotiation of guilty pleas by requiring the use of written pretrial agreements between the accused and the convening authority, ${ }^{72}$ thus foreclosing many of the abuses associated with informal plea bargaining.

The services have also taken significant steps to upgrade the quality of their legal personnel and facilities. The Army, for example, has established a Judge Advocate General's School, which has generated innovative research in military law. The Air Force has created new facilities for retraining and rehabilitating convicted airmen. ${ }^{73}$ And the Navy has introduced the use of stenomask court reporting-a useful means of combating the shortage of conventionally trained court reporters.

More substantial innovation by the services may be expected to result froin the recommendations of the Report of the Task Force on the Administration of Military Justice in the Armed Forces, ${ }^{74}$ prepared for the Department of Defense by a diverse collection of civilians and military officers. Pursuant to that report, the Secretary of Defense has already ordered the impleinentation of some significant reforms, including a requirement that "adequate legal advice" be made available to the accused before any action nnay be taken against him

field commanders. The test period was concluded on November 30, 1971, and is currently undergoing an evaluation with a view toward determining its feasibility for worldwide adoption. 1971 ANNUAL REPORT 33.

A similar approach was suggested in 1962 by Dean A. Kenneth Pye. See 1962 Hearings 548-49. The pilot program has apparently been successful and is being expanded. See AIR Force Judge Advocate General Rep., Aug., 1972, at 21.

71. 1971 ANNUAL Report 3, 21-22.

72. For discussion of the plea-bargaining practices in the various armed services, see 1962 Hearings 843, 870-71, 905, 923, 937. See also United States v. Watkins, 11 U.S.C.M.A. 611, 29 C.M.R. 427 (1960) (expressing the judges' view on the negotiated guilty plea program); McMenamin, Plea Bargaining in the Military, 10 AM. CRrM. L. REv. 93, 94 (1971) (favoring the visibility of the written pretrial agreement). The military procedure tends to avoid problems like those present in Santobello v. New York, 405 U.S. 257 (1971).

73. 1962 Hearings $943-44$.

74. TASK FORCE REPORT. 
under article $15 .^{75}$ The Secretary further ordered that the services take initial steps towards removing all military defense counsel from command control by placing them under the authority of the Judge Advocate General.

\section{A Comparison with Civilian Justice}

\section{Preliminary Caveats}

To ask how, in light of recent developinents, military justice compares with that found in the civilian setting may be misleading. The question inuplies that military justice is monolithic, when such is not the case. For example, the Air Force for many years has experienced a much lighter caseload, both in absolute and im percentage terms, than have the other armed services. ${ }^{76}$ Thus, it was able to provide lawyers as defense counsel in almost all special courts-martial long before this practice became feasible in the other services. Similarly, the Air Force has consistently refused to allow the plea bargaining which is permitted in the other armed services. Moreover, even within a given service, commands may differ im their disciplinary probleins. Fimally, regardless of the particular service, the quality of military justice available at some remote outpost may be inferior to that dispensed at a major installation in the United States.

Similarly, there are many brands of civilian justice. For American personnel stationed overseas, perhaps the most important civilian courts are those of the foreign countries where they are assigned. Many of these countries are subject to basic requirements of procedural

75. Memorandum from Secretary of Defense Melvin Laird to the Secretaries of the Military Departments on the REPORT OF THE TASK ForCe on the AdMINISTRATION of Mituitary Justice in the ARMed Forces, Jan. 11, 1973.

76. This is especially remarkable in light of the fact that the Air Force has over 720,000 personnel, as compared to some 590,000 in the Navy and 200,000 in the Marine Corps. The Army has over 1,120,000 personnel. 1973 World ALMaNac AND BOOK OF FACTS 493-96.

During the fiscal year 1971, the Army tried 2,751 persons by general courtmartial, 27,989 persons by special court-martial, and 14,996 by summary courtmartial-a total of 45,736 persons. 1971 ANNUAL REPoRT 18. During fiscal year 1971, the Air Force convened 194 general courts-martial, 1,896 special courts-martial, and 308 summary courts-martial-a total of 2,398. Id. at 34. Thus, the total number of courts-martial of all types tried in the Air Force during fiscal year 1971 was less than the number of persons tried by general court-martial in the Army. The Navy's figures are below the Army's in all categories but substantially above the Air Force's, the total of all courts-martial being 28,762 for fiscal year 1971. Id. at 32. To some degree, the disparity in the number of courts-martial among the various services reflects, aside from discrepancies in personnel totals, differences in disciplinary policies; but other causes probably include differences in type of personnel and in the mission of the various services. 
fairness imposed by the NATO Status of Forces Agreement ${ }^{77}$ or similar treaties; but these agreements do not purport to afford all the safeguards contained in either the Bill of Rights or the Uniform Code of Military Justice. Ironically, from the standpoimt of accused servicemen, results in foreign civil courts might compare favorably with those either in courts-martial or in American civilian courts, since, although the conviction rate is high, the sentences have tended to be light. ${ }^{78}$

With respect to civilian justice within the United States, the most significant comparison might be between courts-martial and state courts. In view of the limitations on criminal jurisdiction of the federal courts, misconduct of a serviceman, if not tried by court-martial will far more likely be subject to state rather than federal prosecution. Of course, anong the states there are numerous variations in criminal procedure. Some use grand juries; some do not. Some provide for separate trial on an issue of mental responsibility; others do not. In short, the variations are extensive.

In soine respects both the differences in state court procedures and the differences between state and federal criminal procedure have been reduced in recent years. Selective imcorporation of substantial portions of the Bill of Rights into the due process clause of the fourteenth amendment has assimilated state criminal trials more and more to the federal inodel. More recently, however, the Supreme Court lias suggested that certain constitutional guarantees have less scope than might previously have been supposed. ${ }^{70}$ Thus, state courts are being granted greater freedoin to deviate from the criminal procedure employed in the federal courts than is generally recognized.

77. Article VII, paragraph 9 of this Agreement provides for speedy trial, notice of the charges, confrontation, compulsory process, legal representation, an interpreter, and communication with a representative of the accused serviceman's government. NATO Status of Forces Agreement, June 19, 1951, [1953] 4 U.S.T. 1792, T.I.A.S. No. 2846. Of course, these procedural requirements may not have possessed the same meaning for all the countries that signed the agreement. See J. SNEE \& A. PYE, Status of Forces Agreement: Criminal Jurisdiction 94-101, 106-20 (1957). One writer viewed the safeguards required by this Agreement as the precursor to an international Bill of Procedural Rights. See R. ElLert, NATO "FaIR Trial" SAFEGUARDS (1963).

78. This tendency probably reflects in large part the host country's reluctance to be saddled with the expense of providing penal facilities for foreign personnel, whose rehabilitation can be of little or no interest to it-not to mention the host government's usual reluctance to ruffle its diplomatic relations with the United States.

79. See, e.g., Apodaca v. Oregon, 406 U.S. 404 (1972) (state conviction of felony by less-than-unanimous jury verdict held not in violation of right to trial by jury); Willianıs v. Florida, 399 U.S. 78 (1970) (state rule requiring defendant relying on alibi to make pretrial disclosure of alibi witnesses' names to prosecutor held not to violate privilege against self-incrimination). 
Despite the preceding caveats, it seems particularly appropriate to compare briefly some of the procedures and safeguards in courts-martial with those in the federal district courts. Both tribunals are creatures of the same sovereign. ${ }^{80}$ Furthermore, Congress directed that, im prescribing the procedure for courts-martial, the President shall, "so far as he deems practicable, apply the principles of law and the rules of evidence generally recognized in the trial of criminal cases in the United States district courts. . . ."81 And, in defining the proper role of the law officer-now military judge-the Court of Military Appeals has looked to the model of the federal district judge. ${ }^{82}$ Therefore, this discussion adopts the federal district courts as a nodel for the comparison of civilian and military justice.

\section{Grand Jury Indictment}

Only in the fifth amendment does the Bill of Rights contain an express exception applicable to military trials; ${ }^{83}$ and there the exception appears to concern only the requireinent of grand jury indictment. Accordingly, trials by court-nartial are not based on grand jury indictment. $^{84}$ Except for petty offenses or where there has been waiver of indictment, however, a prosecution in a federal district court must stein from an indictment. In $O^{\prime}$ Callahan v. Parker, Justice Douglas reasoned that the severe limitation imposed by that case on military jurisdiction would help preserve a serviceman's right to grand jury indictment. A fallacy of that argument is that a serviceman who is tried by civilian court, rather than court-martial, will usually be tried in a state court. Up to the present time there is no constitutional requirement that state courts use grand juries; ${ }^{85}$ and many states authorize prosecution on information, rather than on indictment. ${ }^{86}$ Thus, despite $O^{\prime}$ Callahan, a serviceman may not receive the protection of a grand jury indictment.

80. Cf. Grafton v. United States, 206 U.S. 333 (1907).

81. U.C.M.J. art. 36, 10 U.S.C. $\$ 836$ (1970).

82. For different opinions concerning this transformation, see Miller, Who Made the Law Officer a "Federal Judge"? 4 MnITARY L. REv. 39 (1959); Quinn, CourtsMartial Practice: A View from the Top, 22 HAsT. L.J. 201, 208-10 (1971).

83. The applicable portion of the fifth amendment reads as follows:

No person shall be held to answer for a capital, or otherwise infamous crime, unless on a presentment or indictment of a Grand Jury, except in cases arising in the land or naval forces .... U.S. Const. amend. V (emphasis added).

84. Chenoweth v. Van Arsdall, 22 U.S.C.M.A. 183, 46 C.M.R. 183 (1973).

85. Hurtado v. Califormia, 110 U.S. 516 (1884), has not yet been overruled.

86. As of 1969, twenty-two states authorized prosecution of felonies by information as well as by indictment. See L. HaLl, Y. Kamisar, W. LaFave \& J. Israel, Modern Crmminal Procedure 788-89 (3d ed. 1969). 
Furthermore, considerable disillusionment has arisen with respect to the grand jury's role as a safeguard for accused persons. Proceedings before a grand jury are in secret, and an accused usually may not even examine the transcript of testimony on the basis of which he was indicted. The prosecutor generally determines which prospective witnesses will testify; and neither a prospective accused nor his counsel is allowed to be present and cross-examine witnesses called before the grand jury. Moreover, failure of one grand jury to return a true bill does not preclude another grand jury from doing so later, as successive grand jury proceedings do not constitute double jeopardy.

Although the Uniform Code does not provide for grand jury indictment, article 32 of the Code does call for pretrial investigation before charges may be referred to a general court-martial ${ }^{87}$ - the only kind of court-martial that can adjudge a sentence of dishonorable discharge, total forfeiture of pay, or confinement for more than six months. Thus, the cases that are not subject to pretrial investigation are somewhat comparable to the "petty offenses" for which neither grand jury indictment nor trial by jury would seem constitutionally required. ${ }^{88}$

The pretrial investigation results in sworn testimony, which is known to the accused and generally subject to cross-examination. If the accused chooses to testify, his own counsel is present to assist him. Thus, with respect to discovery of evidence and opportunity to crossexamine witnesses, the pretrial investigation provides the defendant opportunities that would not be available in civilian courts. A subpoena can be issued to compel a witness to appear before a grand jury. Under the Code's wording it seems doubtful that a subpoena may be issued to compel a witness to testify $\mathrm{m}$ an article 32 pretrial investigation. $^{89}$ In civilian courts the requirement of public trial does not ex-

87. U.C.M.J. art. 32, 10 U.S.C. $\$ 832$ (1970). Also, there must be advice by the convening authority's staff judge advocate, and the convening authority may not refer a charge to a general court-martial unless he has found that it alleges an offense and is warranted by the evidence. Id. art. 34,10 U.S.C. $\$ 834$.

88. Baldwin v. New York, 399 U.S. 66 (1970). See Dyke v. Taylor Implement Mfg. Co., 391 U.S. 216 (1968); Cheff v. Schnackenberg, 384 U.S. 373 (1966); Ex parte Quirin, 317 U.S. 1, 39 (1942); District of Columbia v. Clawans, 300 U.S. 617 (1937); Act of June 25, 1948, 18 U.S.C. $\$ 1$ (1970); Frankfurter \& Corcoran, Petty Federal Offenses and the Constitutional Guaranty of Trial by Jury, 39 HARv. L. Rev. 917 (1926).

89. The Code provides that the "trial counsel, the defense counsel, and the court-martial shall have equal opportunity to obtain witnesses and other evidence." U.C.M.J. art. 46, 10 U.S.C. $\$ 846$ (1970). This wording seems to contemplate a case that has already been referred to a court-martial for trial, although the accused may have a "defense counsel" during the pretrial investigation. Id. art. 32(b), 10 
tend to grand jury proceedings, which are conducted in secret..$^{90}$ It is unclear whether the article 32 investigation is sufficiently akin to a grand jury investigation as to authorize exclusion of the public.

In the federal courts, a United States attorney may not be obligated to prosecute even though a grand jury has indicted; but he cannot go to trial without a grand jury indictment. ${ }^{91}$ A military con1mander, on the other hand, is not bound by the recommendations of the officer who conducts the pretrial investigation required by article 32; the charges may be referred for trial even though the investigator recommends to the contrary. However, it remains debatable whether a military accused is significantly more exposed to a risk of unfair prosecution than a defendant would be in a federal district court. The relationship of a civilian prosecutor to the grand jury usually makes it possible for him to obtain the indictments that he desires. Moreover, it is likely that, as military justice has become more sophisticated and professionalized, the typical commander has become less willing to override a recommendation by an article 32 investigator or by his own staff judge advocate that charges not be referred for trial. Indeed, a commander may have every imclination not to refer borderline cases for trial since a high court-martial rate is sometimes considered an imdication of poor leadership.

\section{Double Jeopardy}

The fifth amendinent's guarantee against double jeopardy is not subject to an express exception for military trials, but the original military practice was apparently quite tolerant of suecessive prosecution. ${ }^{92}$ The Uniform Code, however, has since conferred a protection agamst double jeopardy. ${ }^{93}$ Moreover, by prohibiting a more severe

U.S.C. $\$ 832(\mathrm{~b})$. Article 47 , which proscribes refusal to appear or testify, refers to a person "duly snbpoenaed to appear as a witness before a court-martial, military commission, court of inquiry, or any other military court or board . . ." Id. art. 47, 10 U.S.C. $\S 847$. There is no penalty for failure to appear or testify before an officer appointed to investigate pursuant to article 32 . Since a court of inquiry is included under article 47 and since an investigation by a court of inquiry would probably satisfy the requirements of article 32 under certain circumstances, a court of inquiry might be convened to investigate a suspected offense if it appeared desirable to have the power available to subpoena witnesses to testify concerning the offense.

90. With respect to the secrecy of the grand jury, see Dennis v. United States, 384 U.S. 855 (1966); Pittsburgh Plate Glass Co. v. United States, 360 U.S. 395 (1959).

91. Cf. United States v. Cox, 342 F.2d 167 (5th Cir.), cert. denied, 381 U.S. 935 (1965).

92. See Wiener, Courts-Martial and the Bill of Rights: The Original Practice (pts. 1-2), 72 HARv. L. Rev. 1, 266 (1958).

93. See U.C.M.J. arts. 44, 62-63, 10 U.S.C. $\$ \$ 844,862-63$ (1970). 
sentence in the event of a rehearing, the Code eliminates a danger that, at least in a minor degree, still exists in the civilian courts. ${ }^{04}$

Since a court-martial is a federal tribunal, a serviceman cannot be prosecuted in both a district court and in a court-martial for what amounts to the same conduct. ${ }^{05}$ With respect to prosecution in both a court-martial and a state court, the same rule-whatever it may bewould seem to apply that would govern dual prosecution in a state court and a federal district court. ${ }^{96}$ However, the $O^{\prime}$ Callahan case reduces the possiblity of such successive prosecutions, since conduct that falls within the jurisdiction of the state court often will lack the serviceconnection necessary for court-martial jurisdiction. Furthermore, military policy does not favor these successive prosecutions. ${ }^{97}$

Under habitual offender provisions in the Manual for CourtsMartial, prior military convictions may be a basis for increasing the maximum punishment that may be imposed.98 However, such provisions, whicl1 have parallels in many civilian criminal codes, are not usually considered to involve double jeopardy. Similarly, the use of military convictions to support administrative action unfavorable to the accused-such as undesirable discharge from the armed services ${ }^{99}$-is not deemed to create double jeopardy and has considerable precedent in civilian life. ${ }^{100}$ An attorney, for example, may be disbarred ad-

94. Under North Carolina v. Pearce, 395 U.S. 711 (1969), a heavier sentence may be imposed at a retrial in light of events subsequent to the original trial. This is not permitted under the Uniform Code.

95. Grafton v. United States, 206 U.S. 333 (1907).

96. Abbate v. United States, 359 U.S. 187 (1959); Bartkus v. Illinois, 359 U.S. 121 (1959); United States v. Lanza, 260 U.S. 377 (1922). But cf. Murphy v. Waterfront Comm'n, 378 U.S. 52 (1964).

97. Manual $\llbracket 215 b$.

98. The Manual provides that three or more previous convictions during the year preceding commission of any offense of which the accused stands convicted will authorize dishonorable discharge, total forfeitures of pay and allowances, and confinement for one year. Two or more previous convictions during the three years preceding commission of any offense of which the accused stands convicted will authorize bad conduct discharge, total forfeitures, and confinement for three months. Imposition of nonjudicial punishment is not a prior conviction for these purposes. Id. $\llbracket 127 c$ (6), \& B.

99. See Everett, Military Administrative Discharges-The Pendulum Swings, 1966 DUKE L.J. 41, 58, 78.

100. Conviction of traffic offenses often leads to suspension or revocation of a driver's license. See, e.g., N.C. GEN. STar. \& 20-16 (Supp. 1965). See also, e.g., 41 U.S.C. $\$ \S 10 \mathrm{~b}(\mathrm{~b}), 37$ (1970), authorizing the debarment of bidders who lave violated the Davis-Bacon and Waish-Healy Acts. Civil penalties often are authorized without regard to the results of criminal proceedings which arise from the same facts. See Rex Trailer Co. v. United States, 350 U.S. 148 (1956); United States ex rel. Marcus v. Hess, 317 U.S. 537 (1943); Helvering v. Mitchell, 303 U.S. 391 (1938); Various Iteins v. United States, 282 U.S. 577 (1931). 
ministratively upon the basis of a prior criminal conviction. ${ }^{101}$

\section{Privilege Against Self-Incrimination}

In article 31 the Uniform Code requires that, before a serviceman accused or suspected of an offense may be interrogated or asked for a statement, he must be niformed of the nature of the accusation and advised that he need not make any statement regarding the offense and that any statement he does make may be used in evidence against him in a trial by court-martial. ${ }^{102}$ When the Code took effect in 1951, there was little precedent for this warning requirement. In fact, the Supreme Court later relied on article 31 to help justify the Miranda warning requirement. ${ }^{103}$ Miranda also included the requirement that the accused be advised of his right to counsel, which is not demanded by article 31; but the Court of Military Appeals has since held that Miranda applied fully to the armed services from the date of its decision. ${ }^{104}$ Furthermore, article 31 continues to call for a warning of the right to remain silent without regard to the custodial interrogation that brings Miranda into play. ${ }^{105}$

In its interpretation of the wording of article 31, the Court of Military Appeals has concluded that service personnel may not be compelled to furnish handwriting ${ }^{106}$ or voice exemplars ${ }^{107}$ or even to submit to blood tests ${ }^{108}$ in connection with criminal investigations. The Supreme Court has taken a far more limited view of the protection afforded by the fifth amendinent; ${ }^{109}$ and, as to blood tests at least, the

101. 7 AM. JuR. 2D, Attorneys at Law \$\$ 12-72 (1963).

102. U.C.M.J. art. 31, 10 U.S.C. $\$ 831$ (1970).

103. Miranda v. Arizona, 384 U.S. 436, 489 (1966).

104. United States v. Tempia, 16 U.S.C.M.A. 629, 37 C.M.R. 249 (1967).

105. The Supreme Court has interpreted "custodial interrogation" rather liberally. See Orozco v. Texas, 394 U.S. 324 (1969); Mathis v. United States, 391 U.S. 1 (1968). Thus, the gap between the applicability of article 31 and Miranda has been reduced. In military justice the admissibility of a confession under article 31 must be ruled upon by both the military judge and the military jury, which must disregard it entirely unless convinced beyond a reasonable doubt that it was voluntary. MaNUaL $\mathbb{1} 140 a$. In the civilian setting, however, proof beyond reasonable doubt is not required to establish voluntariness. See Lego v. Twomey, 404 U.S. 477 (1972).

106. United States v. Penn, 18 U.S.C.M.A. 194, 39 C.M.R. 194 (1969); United States v. White, 17 U.S.C.M.A. 211, 38 C.M.R. 9 (1967); United States v. Eggers, 3 U.S.C.M.A. 191, 11 C.M.R. 191 (1953); United States v. Rosato, 3 U.S.C.M.A. 143, 11 C.M.R. 143 (1953). See also United States v. Minnifield, 9 U.S.C.M.A. 373, 26 C.M.R. 153 (1958) (handwriting exemplar constitutes a "statement" for purposes of article 31).

107. United States v. Greer, 3 U.S.C.M.A. 576, 13 C.M.R. 132 (1953).

108. United States v. Musguire, 9 U.S.C.M.A. 67, 25 C.M.R. 329 (1958); cf.

United States v. Jordan, 7 U.S.C.M.A. 452, 22 C.M.R. 242 (1957) (urine specinen). 109. See Gilbert v. California, 388 U.S. 263 (1967); United States v. Wade, 388 U.S. 218 (1967); Schmerber v. California, 384 U.S. 757 (1966). 
most recent Manual for Courts-Martial seems to follow the Supreme Court, rather than the Court of Military Appeals. ${ }^{110}$ Although the President has been delegated broad power to prescribe rules of evidence to be used in military tribunals, this power can only be exercised in a manner consistent with provisions of the Uniform Code. ${ }^{111}$ Thus, it is questionable that the President nnay change the Manual for Courts-Martial to overrule the Court of Military Appeals in its interpretation of the scope of the statutory protection granted by article 31 .

In military law, as under the proposed Federal Rules of Evidence, communications by a patient to his physician are not privileged. ${ }^{112}$ Moreover, a military accused may be compelled to submit to psychiatric examination by government psychiatrists as a condition precedent to the admission at trial of his own psychiatric evidence. ${ }^{113} \mathrm{~A}$ medical or psychiatric examination may not require an article 31 warning, ${ }^{114}$ but prosecution comment on a refusal by the defendant to answer the medical examiner's questions is error. ${ }^{115}$

In civilian courts, regulatory agencies, and legislative committees, grants of immunity have been a useful tool for obtaining incriminating testimony from recalcitrant witnesses. Recently the Supreme Court ruled that the immunity granted need only be against use of the incriminating testimony, rather than against prosecution for the transactions revealed by the testimony. ${ }^{116}$ The Manual for Courts-Martial authorizes certain military commanders to grant immumity froin trial;:117 and since no provision is made for the limited testimomial immumity, it would appear that only the broader transactional immumity can be conferred. Of course, the President could change this situation by issuing an Executive Order which makes appropriate anendments to the Manual.

In both military and civilian life, numerous reporting requirements are encountered; and the required reports inay often prove incrimi-

110. See Manual If 152.

111. U.C.M.J. art. 36(a)-(b), 10 U.S.C. \& 836(a)-(b) (1970).

112. Manual If $151 c(2)$. Rule 504 of the Proposed Federal Rules of Evidence recognizes a psychotherapist-patient privilege, subject to certain exceptions, but does not provide a general physician-patient privilege.

113. United States v. Babbidge, 18 U.S.C.M.A. 327, 40 C.M.R. 39 (1969).

114. Id.; United States v. Malumphy, 12 U.S.C.M.A. 639, 31 C.M.R. 225 (1962); United States v. Baker, 11 U.S.C.M.A. 313, 29 C.M.R. 129 (1960).

115. United States v. Kemp, 13 U.S.C.M.A. 89, 32 C.M.R. 89 (1962).

116. Kastigar v. United States, 406 U.S. 441 (1972).

117. MANUAL If $68 h$. A convening authority and his staff judge advocate are disqualified to participate in the review of a court-martial, if previously they have participated in granting immunity to a Government witness in the case. United States v. Diaz, 22 U.S.C.M.A. 52, 46 C.M.R. 52 (1972). 
nating. Some military commands, for instance, may require servicemen to file a report of any off-base automobile accidents in which they were imvolved. ${ }^{118}$ The O'Callahan decision would seem to eliminate the power of military authorities to require reports on activities that have no service-connection. ${ }^{119}$ In other respects the principles applicable to the serviceman and to the civilian in this area seem to be the same. ${ }^{120}$

\section{Search and Seizure}

In contrast with its demonstrated concern for the protection of servicemen against self-incrimination, Congress has not legislated against unreasonable searches and seizures in the military establishment. However, long before either the enactment of the Uniform Code or the decision in Mapp v. Ohio, ${ }^{121}$ the Manual for Courts-Martial had prohibited unreasonable searches and seizures and excluded from evidence the products thereof. ${ }^{122}$

While the off-post house and property of a serviceman may be searched only under the same rules that apply to a civilian, searches on a military installation may be authorized on the sole authority of a military commander. Of course, a military commander is hardly the "neutral and detached magistrate" who must issue search warrants in the civilian courts. ${ }^{123}$ Whether this constitutes a major disparity depends on the extent to which the typical inagistrate has displayed impartiality and detachment in the issuance of warrants. In any event, the armed services seem to be transferring to "military inagistrates" some of the commander's authority for authorizing searches. ${ }^{124}$

118. See, e.g., United States v. Smith, 9 U.S.C.M.A. 240, 26 C.M.R. 20 (1958).

119. It would be hard to accept the argument that a report was service-connected if all the matters to which it related lacked service-connection. Thus, disobedience of the order to make the report would not be service-connected and so not subject to punishment.

120. See California v. Byers, 402 U.S. 424 (1971); Grosso v. United States, 390 U.S. 62 (1968); Marchetti v. United States, 390 U.S. 39 (1968); Shapiro v. United States, 335 U.S. 1 (1948). (constitutional limitations on reporting requirements). Prosecutions for failure to comply with the reporting requirements of military regulations were mvolved in United States v. Kauffman, 14 U.S.C.M.A. 283, 34 C.M.R. 63 (1963), and United States v. Smith, 9 U.S.C.M.A. 240, 26 C.M.R. 20 (1958). See also Kauffman v. Secretary of the Air Force, 415 F.2d 991 (D.C. Cir. 1969).

121. 367 U.S. 643 (1961).

122. Manual for Courts-Martial, United States II 152 (1951). For the current provision, see MaNuAL II 152.

123. See, e.g., Coolidge v. New Hampshire, 403 U.S. 443 (1971); Aguilar v. Texas, 378 U.S. 108 (1964); Giordenello v. United States, 357 U.S. 480 (1958); Johnson v. United States, 333 U.S. 10 (1948).

124. See note 71 supra and accompanying text. 
Although the Court of Military Appeals has ruled that permission to search may be granted by a commander only upon a showing of probable cause, ${ }^{125}$ it has not yet required that an affidavit be executed setting forth the facts believed to constitute probable cause. ${ }^{126}$ However, the court has encouraged the use of written statements to record the facts constituting probable cause, ${ }^{127}$ and the services seem to be acceding to this judicial persuasion. ${ }^{128}$ Presumably, as military magistrates begin to play a greater part in authorizing searches, there will be even greater insistence on documentation of the grounds for a search.

There have been many complaints from servicemen about "shakedown inspections," whereby, without any showing of probable cause, a general inspection is made of a barracks or other large area. The current Manual for Courts-Martial contains an exception from otherwise applicable restrictions on searclies for "administrative inspections."129 In the parallel situation of administrative inspections in civilian life, the Supreme Court generally requires a court order; but the conditions for obtaining such authorization are less onerous than those for obtaining a search warrant to seek evidence of a crime. ${ }^{130}$ Furthermore, the Court has on at least one recent occasion left possible leeway for administrative inspections in the civilian setting without prior judicial authorization. ${ }^{131}$

125. United States v. Brown, 10 U.S.C.M.A. 482, 28 C.M.R. 48 (1959).

126. For applications of this requirement in the federal courts, see Spinelli v. United States, 394 U.S. 410 (1969); United States v. Ventresca, 380 U.S. 102 (1965).

127. In United States v. Martinez, 16 U.S.C.M.A. 40, 36 C.M.R. 196 (1966), it is suggested that authority to search be in writing and that it set out the facts upon which the authorization is based and the articles to be seized.

128. See United States v. Penman, 16 U.S.C.M.A. 67, 69, 36 C.M.R. 223, 225 (1966).

129. See Manual I 152. After setting forth a restriction on permissible objects of search, the Manual provides that this "restriction does not apply to administrative inspections or inventories conducted in accordance with law, regulation, or custom." Id. In the corresponding paragraph of the $1951 \mathrm{Manual}$, there is no reference to "administrative inspections," but an exception is recognized for the legality of searches made by military personnel "in accordance with nilitary custom." MANUAL For Courts-Martial, UntTed States If 152 (1951). The Court of Military Appeals has been willing to uphold "shakedown" inspections under some circumstances. United States v. Gebhart, 10 U.S.C.M.A. 606, 28 C.M.R. 172 (1959); United States v. Swanson, 3 U.S.C.M.A. 671, 14 C.M.R. 89 (1954).

130. Camara v. Municipal Court, 387 U.S. 523 (1967); See v. City of Seattle, 387 U.S. 541 (1967).

131. See Wyman v. James, 400 U.S. 309 (1971), where the Supreme Court upheld administrative home visitations as a vahid prerequisite to certain welfare benefits. While emphasizing that the visit was not a search in the traditional criminal law context, the Court noted that even if it were so held, the visit was sustainable under the fourth aniendment's test of reasonableness. Id. at 317-18. 
Military courts have not proved blind to the danger that administrative inquiry might become a subterfuge for avoiding the probable cause standard applicable to criminal investigation. ${ }^{132}$ Moreover, it is not unlikely that use of military magistrates to authorize searches will be a precedent for their employment in determining whether administrative inspections should take place. To that extent, a reduction in the incidence of abuse in this area may be anticipated.

For "apprehension"-which is the military term for the civilian concept of arrest ${ }^{133}$-no court order or even authorization from a commander is necessary. However, there must be "reasonable belief that an offense has been committed and that the person apprehended committed it."134 Basically this is the probable cause standard in the civilian setting as well. ${ }^{135}$ Once an arrest has been made, the search incident to arrest may not exceed the guidelines enunciated in Chimel v. California, ${ }^{136}$ limiting search to the area "within the immediate control" of the arrestee.

Military justice makes no express provision for "stop and frisk" but presumably would apply the same rules applicable in the civilian community. ${ }^{137}$ Additionally, the Manual for Courts-Martial does not deal with "no-knock searches" or the manner of entry to search and seize; therefore, the principles of Ker $v$. California, ${ }^{138}$ allowing unannounced entry where there is both probable cause to arrest and "exigent" circumstances, would probably prevail in the military as well as the civilian setting.

Various types of electronic surveillance are deemed by the Supreme Court to involve unreasonable searches for and seizures of conversation. ${ }^{138}$ At one time the Court of Military Appeals ruled that wiretapping was permissible if done outside the United States ${ }^{140}$ or on

132. For a recent case holding that, under the particular facts, the shakedown was a search and not an inspection, see United States v. Lazerus, C.M. 42,877 (Army Court of Military Review, Aug. 15, 1972).

133. U.C.M.J. art. 7, 10 U.S.C. $\& 807$ (1970). The Code uses the term "arrest," on the other hand, to describe "the restraint of a person by an order, not imposed as a punishment for an offense, directing him to remain within certain specified limits." Id. art. 9 (a), 10 U.S.C. $\$ 809$ (a).

134. Id. art. 7(b), 10 U.S.C. $\$ 807$ (b).

135. See, e.g., Henry v. United States, 361 U.S. 98 (1959); Draper v. United States, 358 U.S. 307 (1959).

136. 395 U.S. 752 (1969).

137. For "stop and frisk" cases, see Sibron v. New York, 392 U.S. 40 (1968); Terry v. Ohio, 392 U.S. 1 (1968).

138. 374 U.S. 23 (1963).

139. Katz v. United States, 389 U.S. 347 (1967); Berger v. New York, 388 U.S. 41 (1967).

140. United States v. Gopaulsingh, 5 U.S.C.M.A. 772, 19 C.M.R. 68 (1955). 
a purely military telephone system. ${ }^{141}$ These holdings, which were predicated on the court's interpretation of section 605 of the Communications Act, ${ }^{142}$ have not been reexamined in light of the Supreme Court's decisions, which rely on the fourth amendinent. It seems probable, however, that they would no longer apply and that service personnel would be no more vulnerable to electronic surveillance than their civilian counterparts. Moreover, the armed services liave themselves imposed strict limitations on electronic surveillance. ${ }^{143}$

Military judges are not yet included among the judges who are empowered to issue orders authorizing the interception of wire or oral communications. ${ }^{144}$ Thus, if law enforcement agents wish to place a serviceman under electromic surveillance, authority must be sought from a federal district or circuit court judge-or, in certain emergency situations, from the Attorney General. ${ }^{145}$

Since the scope of the fourth amendinent's protection from unreasonable search and seizure is often couched in terms of the complainant's "reasonable expectations of privacy" in a given situation, ${ }^{140}$

141. United States v. Noce, 5 U.S.C.M.A. 715, 19 C.M.R. 11 (1955).

142. Communications Act, 47 U.S.C. $\$ 605$ (1962), as amended, 47 U.S.C. $\& 605$ (1970) (pursuant to the Omnibus Crime Control and Safe Streets Act of 1968, Pub. L. No. 90-351, 82 Stat. 197 (codified in scattered sections of 5, 18, 18 App., 28, 42, 47 U.S.C.) ).

143. See, e.g., Use of Wiretapping and Eavesdropping in Conduct of Investigations, Air Force Reg. No. 124-18 (July 23, 1970); Early, Interception of Communications by Air Force Agents, 10 AIR ForCe Judge Advocate General L. Rev. 8 (1968).

144. See 18 U.S.C. $\$ \$ 2510(9), 2516$ (1970). The Task Force Report recommends that military judges be cast in the image of civilian judges and be granted added powers-among them the power to issue search warrants based on probable cause. TASK FORCE REPORT 83-85, 124. However, the Report does not deal expressly with the nuatter of extension of the provisions of the Omnibus Crime Control and Safe Streets Act of 1968 to permit military judges to issue orders for the interception of wire or oral communications.

145. Omnibus Crime Control and Safe Streets Act of 1968, 18 U.S.C. $\S 2518(7)$ (1970), providing:

[A]uy investigative or law enforcement officer, specially designated by the Attorney General or by the principal prosecuting attorney of any State or subdivision thereof acting pursuant to a statute of that State, who reasonably determines that-(a) an emergency situation exists with respect to conspiratorial activities threatening the national security interest or to conspiratorial activities characteristic of organized crime that requires a wire or oral comnunication to be intercepted before an order authorizing such interception can with due diligence be obtained, and (b) there are grounds upon which an order could be entered under this chapter to authorize such interception, may intercept such wire or oral communication if an apphication for an order approving the interception is nuade ... within forty-eight hours after the interception has occurred, or begins to occur.

The definition of "investigative or law enforcement officer" in 18 U.S.C. $\$ 2510(7)$

(1970) would seent to include certain categories of miktary officials.

146. Katz v. Umited States, 389 U.S. 347, 360 (1967) (concurring opinion). 
it might be contended that fourth amendment protections are attenuated in those situations where servicemen are billeted together in a barracks. Given the relatively unrestrained entry of both residents and nonresidents into a barracks, it would seem that the expectation of privacy of the personnel living in a barracks would necessarily be less than that of a civilian dwelling in a private home. The extent to which such considerations might lower the level of fourth amendment protections available to the barracks-dwelling serviceman presents troublesome questions beyond the scope of this Article.

\section{Right to Counsel}

The Military Jnstice Act of 1968 required that an accused be provided legally qualified counsel to represent him not only in general courts-martial but also in almost all special courts-martial. ${ }^{147}$ Furthermore, if he is brought to trial before a summary court-martial, an accused lias an absolute statutory right to object thereto, in whicl event he can only be tried by special or general court-1nartial. ${ }^{148}$ If offered nonjudicial punishment, the accused-unless he is attached to or embarked in a vessel-may decline to accept nonjudicial punishment. ${ }^{149}$ In that event the charge may be referred to a court-martial for trial; but, if the charge is referred to a summary court-martial, the accused still has the right to object to trial by that tribunal. ${ }^{150}$ Thus, as a practical matter, a serviceman who wishes to be represented by a military lawyer has been provided by statute with the means to obtain such representation, no matter how minor the offense with which he is

147. U.C.M.J. art. 27 (c), 10 U.S.C. $\$ 827$ (c) (1970). If a military lawyer cannot be provided as defense counsel because of "physical conditions or military exigencies," then the convening authority "shall make a detailed written statement, to be appended to the record, stating why counsel with such qualifications could not be obtained." Id. For the punitive scope of special courts-martial, see id. art. 19, 10 U.S.C. $\$ 819$; note 14 supra.

148. Id. art. 20, 10 U.S.C. $\$ 820$.

149. Id. art. 15(a), 10 U.S.C. $\$ 815(\mathrm{a})$. The Task Force has also recommended that a "serviceman have the right to obtain the advice of legally-qualified military counsel before deciding whether to demand trial in lieu of non-judicial punishment (except in those situations when the exigencies of the service limit the availability of counsel)." TASK FORCE REPORT 120. Furthermore, the accused should receive a "personal hearing before the commander contemplating the imposition of punishment"; and at this hearing he should have the right "to be accompanied by an available personal representative, who may but need not be a lawyer, to advise him and to make a statement on his behalf." Id.

150. U.C.M.J. art. 20,10 U.S.C. $\$ 820$ (1970). In this respect there has been a change in article 20 of the Uniform Code as it was originally enacted; under that provision an accused could not object to trial by summary court-martial if le had previously been offered nonjudicial punishment. 
charged. Moreover, the Secretary of Defense has recently directed that "adequate legal advice" be made available to the accused prior to the imposition of nonjudicial punishment. ${ }^{151}$ It is not as yet clear whether the "adequate legal advice" criterion is to be equated with the provision of legally qualified counsel, although that analysis would appear to be the most likely imterpretation. Given the complexity of the options available to the accused under article 15's nonjudicial punishment procedures and the serious implications of waiver, it is unlikely that a non-lawyer could provide "adequate legal advice" in most situations.

Until the Supreme Court's decision in Argersinger v. Hamlin, ${ }^{152}$ it had seemed likely that the constitutional obligation to provide lawyers for indigent criminal defendants in civilian courts did not extend to "petty offenses," where the confinement imposable was six months or less. Now no confinement seems imposable if counsel has not been offered to the defendant. Since summary courts-martial have jurisdiction to try enlisted personnel and to impose up to thirty days' confinement, Argersinger has placed in question the validity of convictions by such courts if counsel was unavailable. In view of the election available to an accused to object to the jurisdiction of a summary courtmartial, it might be argued that, at least if he has been properly advised of his rights, failure to make such objection constitutes a waiver of the right to counsel. On the other hand, the severe consequences that may result froin objecting to the jurisdiction of a summary courtmartial make less plausible the contention that failure to exercise that election has the element of conscious choice requisite for valid waiver of a constitutional right. ${ }^{153}$ Two federal district court decisions have ex-

151. In January, 1973, Secretary of Defense Laird directed the military departments to revise their procedures for nonjudicial punishment

to require: a. The availability of adequate legal advice to an accused person prior to action by Commanders authorized to impose punishment; $b$. The opportunity for full presentation by an accused person of his case in the presence of his or lier Commander, to include but not limited to the right to call witnesses, present evidence and to be accompanied by a person to speak on his or her behalf . . . . Meinorandum froin Laird, supra note 75.

The memorandum does not contain the qualifying exception for "situations when the exigencies of the service limit the availability of counsel," a reservation which appears in the Task Force Report. See note 149 supra. If the Laird memorandum intended to preclude such an exception, then its impact on procedures for nonjudicial punishment would be especially great, since far-flung vessels and outposts might lack attorneys to provide the accused person with the desired legal advice.

152. 407 U.S. 25 (1972).

153. For discussion of waiver of counsel, see Von Moltke v. Gillies, 332 U.S. 708 (1948); Adams v. United States ex rel. McCann, 317 U.S. 269 (1942); Johnson v. Zerbst, 304 U.S. 458 (1938). See also Miranda v. Arizona, 384 U.S. 436 (1966). Among the important matters for which an accused might need legal advice before deciding whether to object to trial by summary court-martial are these: (1) convic- 
pressly adopted the latter rationale in holding that the Argersinger rightto-counsel requirements apply with full force to summary courtsmartial. ${ }^{154}$ Moreover, a number of rulings by the Army's Judge Advocate General lend further support to this trend. ${ }^{165}$ These developments may lead to the demise of the summary court-martial-which to many would not seem an undesirable eventuality. ${ }^{156}$

tion by a summary court-martial is a conviction by a federal court for various purposes; (2) convictions by a summary court-martial can be considered in subsequent trials for purposes of permissible additional punishments, MANUAL II $127 c$, $\$ \mathrm{~B}$; (3) conviction by a summary court-martial may be used at some later time to impeach the credibility of the person convicted, id. $\Uparrow 153 b(2)$ (b); (4) convictions by summary court, hike other convictions, may be utilized as a basis for unfavorable administrative discharge action; (5) military defense counsel normally will not be provided to the accused to aid in his defense before a summary court; (6) if, however, he objects to trial by summary court-martial, the case may be referred to a special or general court-martial where the accused may receive a more severe sentence (see note 41 supra).

154. Henry v. Wamer, 41 U.S.L.W. 2598 (C.D. Cal. Apr. 13, 1973); Daigle v. Warner, 348 F. Supp. 1074 (D. Hawaii 1972). The Henry and Daigle courts rejected outright the Government's contention that the accused's right to opt for a general or special court-martial, both of which provide the right to counsel, was sufficient to meet the requirement of Argersinger. To so hold, in light of the more severe punishments imposable by the general and special courts-martial, would punish the accused "for the exercise of one's constitutional rights." Henry v. Warner, 41 U.S.L.W. 2598 (C.D. Cal. Apr. 13, 1973), citing United States v. Jackson, 390 U.S. 570, 582-83 (1968); Daigle v. Warner, 348 F. Supp. 1074, 1080 (D. Hawaii 1972), citing United States v. Jackson, 390 U.S. $570,582-83$ (1968).

155. In four summary court-martial cases, the Judge Advocate General of the Army has set aside the confinement portion of the sentence since the accused were neither represented by lawyer counsel at trial nor did the accused knowingly and intelligently waive their right to representation by lawyer counsel. 72-14 JUDGE ADvoCate Legal Service § III(3) (DA Pam. 1972). It could be argued, consistent with the Argersinger ruling, that the right to counsel only applies to a summary courtmartial in instances where a sentence to confinement is imposed, regardless of the summary court's jurisdiction to impose confinement. This position would contrast with that taken in those cases which draw a dividing line between petty offenses and other crimes for purposes of trial by jury and grand jury indictment. There the test has generally been the punishment that could be imposed, rather than that which is imposed. Cases cited note 88 supra. However, the convening authority's election to refer the case for trial by summary court-martial without providing the accused a military defense attorney might be considered equivalent to a direction by the convening authority that no confinement be imposed by the summary court. A similar problem of constitutional right to counsel exists with respect to nonjudicial punishment which, for enlisted personnel "attached to or embarked in a vessel," may include "confinement on bread and water or diminished rations for not nore than seven consecutive days," or for enlisted personnel geuerally, "correctional custody for not more than seven consecutive days." U.C.M.J. art. 15(b)(2), 10 U.S.C. \& $815(b)(2)(1970)$. Since "correctional custody" differs' from "confinement" in soine respects, see MaNual ITा $131 c(4)$, (5), is correctional custody subject to the Argersinger principle?

156. The Secretary of Defense directive requiring "adequate legal advice" prior to the imposition of nonjudicial punishment would seem to obviate even further the need for the summary court-martial, in that it would encourage more personnel to accept 
Civilian courts require some claim or assertion of indigency on the part of a defendant who wishes to have counsel assigned to represent him. In courts-martial, however, military counsel will be appointed where otherwise required, regardless of the wealth of the accused. Of course, if the accused wishes representation by civilian counsel he must pay for this from his own pocket. ${ }^{157}$

The availability of military defense counsel does not end with the trial. If the sentence includes a dishonorable or bad conduct discharge or confinement for as much as one year, qualified appellate defense counsel is provided to assist the accused ${ }^{158}$-again without any requirement that the accused assert his indigency. Moreover, the defendant and his counsel are furnished a verbatim transcript of the trial. Although the military lawyer who represented the accused at trial would normally not serve as his appellate defense counsel, this would create no real disadvantage simce the appeal is on the record.

Generally, military defense attorneys are not allowed to represent their military clients in a collateral attack on a court-martial action in a federal district court or in the Court of Claims. ${ }^{150}$ However, they may participate in the collateral attacks permitted within the system of military justice; and these military remedies normally must be exhausted before resort to the civilian courts. ${ }^{100}$ Indeed, the requirement of exhaustion of the broad array of military remedies available will usually render innocuous the inabilility of military defense counsel to seek relief in the civilian courts.

Since the enactment of the Military Justice Act of 1968, the real issue concerning right to counsel in military justice is not the availability of military defense counsel but their skill and independence. Because of difficulties encountered by the armed services in retaining

nonjudicial punishment rather than to opt for a summary or special court-martial. See note 151 supra.

157. MANUAL $\pi 48 a$. The Task Force recommends that "[i]n view of the critical need for more mimority lawyers, the feasibility of contracting for a pool of minority civilian defense counsel from which the military could draw, as needed, be explored." TASK FORCE REPORT 125.

158. U.C.M.J. arts. $66(\mathrm{~b}), 70(\mathrm{c}), 10$ U.S.C. $\S \S 866(\mathrm{~b}), 870(\mathrm{c})$ (1970); see MANUAL If $48 k(3)$.

159. The Court of Military Appeals has refused to order the armed services to allow military defense counsel to participate in collateral attacks in the civil courts. Johnson v. Judge Advocate General, 21 U.S.C.M.A. 520, 45 C.M.R. 294 (1972). However, there have been legislative proposals to remove restrictions on such activity by military lawyers. See, e.g., Bayh, supra note 10, at 19; Sherman, supra note 10, at 47 .

160. For commentary on exhaustion of remedies, see articles cited note 9 supra. See also Noyd v. Bond, 395 U.S. 683 (1969). 
judge advocates, it often occurs that young and relatively inexperienced lawyers are assigned to defend serious cases. However, the military attorney assigned to prosecute will often have no inore, or perhaps even less, experience, thus diminishing the potential inequities. Furthermore, the armed services have established excellent legal education programs to inform their lawyers concerning current developments in criminal law and procedure. Whatever madequacies the military system may have in this regard, it is apparent that the same defects may be found in the civilian courts, where young and inexperienced counsel are likewise commonly assigned to defend serious criminal cases.

It has been suggested that some military defense counsel are inhibited by a fear that successful representation of the accused will harm their own military careers and result in poor assignments. The Military Justice Act of 1968 amended article 37 of the Code in a inanner designed to prevent such a fear by prohibiting reporting officers from basing negative fitness reports upon defense counsel's zeal in defending his chent. ${ }^{161}$ More importantly, the Secretary of Defense has recently directed the armed services to take positive steps towards placing defense counsel under the authority of the Judge Advocate General, a step which would go a long way towards eliminating prejudicial command influence. ${ }^{162}$

The Air Force has already instituted a pilot project wherein certain military lawyers are removed from the authority of a commander

161. See U.C.M.J. art. 37, 10 U.S.C. \& 837 (1970). The Code now provides that in the preparation of any report or document which may be used in determining promotions, assignments, or retention on duty, no one preparing the report may "give a less favorable rating or evaluation of any member of the armed forces because of the zeal with which such member, as counsel, represented any accused before a courtmartial." Id. art. 37(b)(2), 10 U.S.C. $\$ 837(\mathrm{~b})(2)$. Despite these statutory safeguards for defense counsel, the Report of the Task Force on the Administration of Military Justice in the Armed Forces found:

Many enlisted men voiced a lack of confidence in military defense counsel.

They believe that defense counsel are not truly representing the interests of the accused, but rather are serving the commander. The Task Force found that there were many dedicated, able and enthusiastic judge advocate defense counsel who defend their clients to the utunost of their ability; yet this perception of duplicity exists. TASK FORCE REPORT 81-82.

In light of this finding, the Task Force recommended that, "[a]ll judge advocate defense counsel be placed under the direction of the appropriate Judge Advocate General ...." Id. at 124-25.

162. On January 11, 1973, Secretary Laird directed the secretaries of the military departments "to submit plans to revise the structure of the Judge Advocate organizations to place defense counsel under the authority of the Judge Advocate General ...." Memorandum from Laird, supra note 75. See text accompanying note 75 supra, 
in the field. This arrangement is designed to provide the same type of independence enjoyed by military judges in the Trial Judiciary. However, it is undeniable that even if placed outside the command of any officer who convenes courts-martial, defense counsel will still be dependent on superior officers within the armed services for promotion, assignments, and, if they desire it, retention on duty; and there is always the possibility that the defense lawyer will act less vigorously for an accused because he fears soine form of retaliation.

To put the comparison with civilian justice in perspective, it should be recalled that defense counsel in civilian courts are not immune from various types of temptations and pressures. The lawyer representing an unpopular client may fear loss of his practice. Or he may be mclined to plead a client guilty after minimum investigation of the case in order to collect a fee and get back to his office. Moreover, if the military accused is concerned about the independence and enthusiasm of his appointed defense counsel, he inay ask that a military defense counsel be assigned to represent him from another command-or even from another armed service. Alternatively, if he has adequate funds lie may obtain civilian counsel.

\section{Trial by Jury}

The sixth amendment guarantees trial by an impartial jury; but more than a century ago the Supreme Court indicated that this guarantee, like that of grand jury indictment, did not apply to cases arising in the armed forces. ${ }^{163}$ While there have been recent attacks on this conclusion and arguments that, apart from sixth amendment protections, the method of selecting the members of a court-martial deprives the accused of due process, ${ }^{164}$ to hold unconstitutional the presently existing procedures for selecting court-martial members would constitute a startling and belated break with precedent. ${ }^{165}$

Currently the members of general and special courts-martial are appointed by the convening authority-the military commander who convenes the court. If the accused is an officer, all the members of the court-martial will be officers, usually of higher rank than the ac-

163. Ex parte Milligan, 71 U.S. (4 Wall.) 2, 123, 138 (1866). Cf. Dynes v. Hoover, 61 U.S. (20 How.) 65 (1857).

164. See Remcho, Military Juries: Constitutional Analysis and the Need for Reform, 47 IND. L.J. 193 (1972).

165. See, e.g., United States v. Kemp, 22 U.S.C.M.A. 152, 46 C.M.R. 152 (1973), holding that courts-martial are not part of the judiciary within the meaming of article III of the Constitution and that therefore any sixth amendment requirements with regard to jury selection have no application to the selection of court-martial members. 
cused. If the accused is an enlisted man, the court members will be officers unless the accused has made a written request prior to trial that at least one third of the members be enlisted persons. ${ }^{168}$ The convening authority is enjoined by the Uniform Code to appoint such persons as, in his opinion, "are best qualified for the duty by reason of age, education, training, experience, length of service, and judicial temperament."167 A general court-martial must have at least five inembers at all times, and a special court-nartial, three members. However, no ceiling applies to the number of court members. Unless the accused elects to be tried solely by a military judge, both findings and sentence are determined by the court members. Conviction requires a twothirds written vote of the members present at the time the vote is taken. ${ }^{188}$ Sentences also require a two-thirds vote, except that sentences to confinement for more than ten years require a three-fourths vote and death sentences necessitate a unaninious vote. ${ }^{169}$

Federal courts have traditionally used twelve-member juries in criminal cases and have required a unanimous verdict. Perhaps because of the well established federal procedure, it was long assumed by many that article III and the sixth amendment made necessary a jury of this size and a unanimous verdict. But in interpreting the guarantee of trial by jury, as incorporated in the due process clause of the fourteenth amendment, the Supreme Court has now made clear

166. U.C.M.J. art. 25(c)(1), 10 U.S.C. $\& 825$ (c)(1) (1970). The written request for enlisted members must be personally signed by the accused. United States $v$. White, 21 U.S.C.M.A. 583, 45 C.M.R. 357 (1972).

167. U.C.M.J. art. 25(d)(2), 10 U.S.C. § 825(d)(2) (1970). Many commanders have relied on this provision in appointing only senior noncommissioned officers to those courts-martial where the accused requested enlisted niembership, and this practice has received judicial approval. United States v. Crawford, 15 U.S.C.M.A. 31, 35 C.M.R. 3 (1964). However, in a later case the Court of Military Appeals disapproved the composition of a court-martial whose members were all of the rank of lieutenant colonel or above. United States v. Greene, 20 U.S.C.M.A. 232, 43 C.M.R. 72 (1970). More recently, the Court has npheld the practice whereby a convening anthority delegates to his subordinate commanders the task of selecting prospective court-martial members whom he ultimately appoints to a particular court-martial. United States v. Kemp, 22 U.S.C.M.A. 152, 46 C.M.R. 152 (1973).

168. U.C.M.J. art. 52(a)(2), 10 U.S.C. \& 852 (a)(2) (1970). However, for conviction of an offense for which the death penalty is mandatory, a unamimous vote is required. Id. art. 52(a)(1), 10 U.S.C. $\$ 852$ (a)(1). Only article 106 of the Code, id. art. 106, 10 U.S.C. $\$ 906$, which punishes spies, provides for a mandatory death sentence; and so as a practical matter, courts-martial determine guilt on a two-thirds vote. The voting on findings and sentence are by secret written ballot. Id. art. 51(a), 10 U.S.C $\$ 851$ (a). Under article 51(c) the presumption of innocence and reasonable doubt apply to the vote on the findings. Id. art. 51(c), 10 U.S.C. \& 851(c). Cf. In re Winship, 397 U.S. 358 (1970), which establishes that dne process includes a requirement of proof of guilt beyond reasonable doubt in a criminal proceeding.

169. U.C.M.J. art. 52(b), 10 U.S.C. \& 852(b) (1970). 
that the Constitution does not include these elements in trial by jury. ${ }^{170}$ Thus, courts-martial-with their less than unanimous verdicts and their membership usually considerably less than twelve-are less at odds with trial by jury than was once supposed.

Neither in state nor in federal criminal trials is trial by jury constitutionally required for "petty offenses"-those offenses for which the punishment imposable does not exceed six months' confinement. ${ }^{171}$ Since a special court-martial may not adjudge more than six months' confinement, ${ }^{172}$ its jurisdiction might in one sense seem limited to petty offenses. However, since special courts-martial can also adjudge as punishment a bad conduct discharge, ${ }^{173}$ which imposes considerable stigma on the recipient, it seems more appropriate to conclude that special court-martial jurisdiction does go beyond trial of petty offenses. Consequently, to the extent that the constitutional provisions requiring trial by jury may be held to bear any applicability to military cases, they should govern special as well as general courts-inartial.

Over the years trial by jury has come to include a requirement that the jury contain a representative cross section of the community. ${ }^{174}$ The Jury Selection and Service Act of $1968^{175}$ was intended by Congrcss to bring federal juries closer to this standard. However, more recently the Supreme Court has upheld the right of the states to set their own requirements of intelligence, good reputation, and the like for jury service. ${ }^{176}$ The Uniform Code's standards for appointment to

170. Apodaca v. Oregon, 406 U.S. 404 (1972) (due process does not require unanimous verdict in state court cases); Williams v. Florida, 399 U.S. 78 (1970) (sixmember juries are permissible in state courts). Because of the division of views among the Justices in Apodaca, the Court apparently would be unwilling to dispense with the unanimity requirement for federal juries. Justice Brennan's dissent notes the anomaly that results when the Court purports to be applying the same requirement of trial by jury to federal and state courts but insists that only federal courts demand a unanimous verdict. Johnson v. Louisiana, 406 U.S. 356, 395 (1972) (dissenting opinion for Johnson and Apodaca).

171. Baldwin v. New York, 399 U.S. 66 (1970); Frank v. United States, 395 U.S. 147 (1969); Duncan v. Louisiana, 391 U.S. 145 (1968); District of Columbia v. Clawans, 300 U.S. 617 (1937).

172. U.C.M.J. art. 19, 10 U.S.C. \& 819 (1970).

173. Id. The Court of Military Appeals has stated: "Considering the consequences of a bad conduct discharge, we entertain no doubt that confmement at hard labor for six months and a forfeiture of pay for a like period is a less severe penalty." United States v. Brown, 13 U.S.C.M.A. 333, 336, 32 C.M.R. 333, 336 (1962).

174. See Remcho, supra note 164 , at 208.

175. 28 U.S.C. $\S \$ 1861$ et seq. (1970).

176. Carter v. Jury Comm'n, 396 U.S. 320 (1970). Cf. Turner v. Fouche, 396 U.S. 346 (1970). The Supreme Court has also allowed considerable leeway to the states in providing for peremptory challenges. Swain v. Alabama, 380 U.S. 202 (1965). In courts-martial each accused and the trial counsel-i.e., the Government- 
membership on a court-marital seem consistent with the criteria for jury selection which have been upheld as constitutional. Of course, the military procedure, with its requirement that officers constitute at least two thirds of the court-martial, is the antithesis of random selection; the convening authority is enjoimed to select the court members on the basis of qualifications that would not conduce to representativeness. It is in this aspect that the composition of the court-martial might be deemed most vulnerable to constitutional attack.

In addition to their unrepresentativeness, courts-martial are subject to the complaint that their members are subject to the control or influence of the convening authority-the military commander who appointed them to the court. Indeed, that commander might have selected for membership the very persons whom he believed he could influence. By strengthening prohibitions against command influence, such as the imsulation of performance on a court-martial from adverse comments in fitness reports, Congress sought in the Military Justice Act of 1968 to lessen these dangers. ${ }^{177}$ Additionally, the Act granted an accused the right, with the military judge's consent, to waive trial by jury and be tried by the judge alone; ${ }^{178}$ and, unlike in federal district courts, ${ }^{179}$ this waiver does not require the approval of the Government.

The widespread use of waiver of jury by military accused may have one or more of these explanations: (a) distrust of military juries on the part of the accused and a corresponding willingness to gamble on a fairer trial by a military judge alone; (b) belief by the accused

are entitled to one peremptory challenge. U.C.M.J. art. 41 (b), 10 U.S.C. $\S 841$ (b) (1970). The Task Force recommends that "[a]dditional peremptory challenges to the court members be permitted by both prosecution and defense, with the defense having a greater number than the prosecution." TASK FORCE REPORT 125. The Federal Rules of Criminal Procedure provide that in capital cases each side is entitled to twenty peremptory challenges; in felony cases, the Government is entitled to six peremptory challenges and the defendant or defendants jointly, to ten; in misdemeanor cases, each side is entitled to three peremptory challenges. FED. R. CRIM. P. 24(b).

177. Article 37 of the Uniform Code was amended to deal with some of the possible abuses that had been unveiled by legislative hearings and judicial opinions. Act of Oct. 24, 1968, Pub. L. No. 90-632, \& 2, 82 Stat. 1338, amending 10 U.S.C. $\$ 837$ (1958) (codified at 10 U.S.C. $\$ 837(1970)$ ).

178. U.C.M.J. art. $16(1)(B),(2)(C), 10$ U.S.C. $\$ \$ 816(1)(B),(2)(C)$. The request for trial by military judge alone must be made before the court is assembled but after consnltation with defense counsel; and the accused must know the identity of the military judge. $I d$.

179. Rnle 23(a) of the Federal Rules of Criminal Procedure requires "approval of the court and the consent of the government." FED. R. CRrM. P. 23(a). The requirement for Government consent was npheld in Singer v. Umited States, 380 U.S. 24 (1965). 
that, in order to have sentence passed by the military judge, ${ }^{180}$ it is worthwhile to waive the right to fact-finding by a military jury; or (c) a reputation for leniency or defense sympathies on the part of the military judge who has been assigned to the case. ${ }^{181}$ Whatever its explanation, the waiver of trial by the full court-martial, combined with enhanced independence, experience, and confidence on the part of military judges, has tended to lessen in the military some of the dangers against which the guarantee of jury trial helps protect defendants in the civilian courts. ${ }^{182}$

\section{Independence of the Judge}

By providing life tenure for federal judges, ${ }^{183}$ the Constitution sought to assure their independence. Courts-martial have been criticized because they do not provide the accused a similar protection of trial before an independent judge. The Military Justice Act of 1968, building upon an innovation of the armed services, transformed the position of "law officer" into that of "military judge." It also required

180. Military law currently makes no provision for waiver of sentencing by the court-martial members in cases where they determine guilt or innocence. However, the Court of Military Appeals and the Judge Advocates General are considering proposals to transfer sentencing power to the military judge in all cases not involving the death penalty. See 1971 ANNUAL RePORT 2. The Report of the Task Force also recommends that military judges be empowered to adjudge the sentence in every noncapital case where there is a finding of guilty and also to suspend the execution of sentences they impose. TASK FORCE REPORT 124.

181. Since he is aware of the identity of the military judge who will try his case, the accused is in a position, with his defense counsel's aid, to evaluate intelligently the probabilities that he might obtain better results by waiving trial by jury. In fact, the percentage of waivers has been quite great. See note 34 supra. It may be disputed whether this circumstance amounts to a vote of confidence in military judges or simply a vote of no confidence in military juries. Perhaps some military judges have tended towards lemiency in order to encourage waiver of jury trials, with the resultant saving of time for prospective court-martial members.

182. According to the Supreme Court:

The purpose of the jury trial, as we noted in Duncan, is to prevent oppression by the Government. . . Given this purpose, the essential feature of a jury obviously lies in the imterposition between the accused and his accuser of the commonsense judgment of a group of laymen, and in the conımunity participation and shared responsibility that results from that group's deter-

mination of guilt or innocence. Williams v. Florida, 399 U.S. 78, 100 (1970).

In light of the American tradition of independence for members of the judiciary, it seems plausible that military judges would form a firmer bastion for accused persons against oppression and injustice at the hand of military commanders than would bo provided by the military persounel typically detailed to serve as court-martial members. Of course, trial by military judge alone does not induce a sense of "community participation and shared responsibility"-and all the less so if the military judge comes from some distant post to try the case.

183. U.S. ConsT. art. III, $\$ 1$. 
that the military judges assigned to conduct general courts-martial be insulated from the control of convening authorities or other military commanders in the field. ${ }^{184}$

In several respects, however, the military judge still lacks some of the authority possessed by his civilian counterpart. In some instances he can be overruled by a convening authority. ${ }^{185} \mathrm{He}$ does not have the authority to grant extraordinary judicial relief pursuant to the All Writs Act. ${ }^{186}$ He lias no regular term of office. Of special importance, he does not participate in sentencing unless an accused has completely waived trial by jury. ${ }^{187}$ Despite these limitations, the military judiciary is acquiring enhanced imdependence and importance; and its scope of authority is being expanded apace. Thus, the Air Force recently announced that it will provide full-time military judges for many of its special courts-martial. ${ }^{188}$ The Army is using military judges as magistrates to authorize release from pretrial confimement and to rule on applications for permission to search and seize. ${ }^{189}$ It seems imevitable that Congress and the armed services will continue to expand the role of military judges and to use them as a protection against abuses that might otherwise accompany the absence of jury trial in military justice.

\section{Speedy Trial}

In civilian courts trial must be speedy; ${ }^{190}$ this same right is recognized by the Uniform Code ${ }^{191}$ and has been upheld by the Court of Military Appeals. ${ }^{192}$ Thus, in dealing with pretrial restraint of the defendant, the Code commands that "immediate steps sliall be taken to inform him of the specific wrong of which he is accused and to try him

184. See note 26 supra and accompanying text.

185. See, e.g., United States v. Frazier, 21 U.S.C.M.A. 444, 56 C.M.R. 218 (1972); Priest v. Koch, 19 U.S.C.M.A. 293, 41 C.M.R. 293 (1970).

186. While there have been holdings that the All Writs Act, 28 U.S.C. \& 1651 (1970), applies to the Court of Military Appeals and the Courts of Military Review, military judges probably do not fall within the Act. There are legislative proposals to authorize military judges to issue all writs appropriate to the exercise of their jurisdiction. See Bayh, supra note 10 , at 16.

187. There is no procedure currently available for waiving trial by jury solely with respect to sentencing. However, without regard to waiver, sentencing power may ultimately be transferred to military judges in all but capital cases. See note 180 supra.

188. See note 70 supra.

189. See note 71 supra and accompanying text.

190. Klopfer v. North Carolina, 386 U.S. 213 (1967).

191. See, e.g., U.C.M.J. arts. 10, 33, 98, 10 U.S.C. $\$ \$ 810,833,898$ (1970).

192. See, e.g., United States v. Williams, 16 U.S.C.M.A. 589, 37 C.M.R. 209

(1967). The burden of proof rests on the government to justify delay in forwarding charges. United States v. Mason, 21 U.S.C.M.A. 389, 45 C.M.R. 163 (1972). 
or to dismiss the charges and release him."103 Furthermore, it is a crime for military personnel to be "responsible for unnecessary delay in the disposition of any case of a person accused of an offense under this code." 104

To enforce the serviceman's right to speedy trial, the armed serices have required specific justification for noncompliance with prescribed standards for processimg military prosecutions. In the Air Force, for example, these standards now allow eighteen days from initiation of pretrial restraint to the end of trial by special court-martial, and forty-five days from date of pretrial restraint to end of a trial by general court-martial. ${ }^{105}$ These requirements of prompt processing certainly contrast with the malady of delay and congestion that has afflicted many civilian courts. ${ }^{106}$

\section{Public Trial}

Under the sixth amendment, a trial must be public as well as speedy. The right to public trial is recognized by the Manual for CourtsMartial ${ }^{197}$ and by the decisions of the Court of Military Appeals. ${ }^{108}$ Apparently the court would apply to this right the same exceptions as those approved by civilian precedents. ${ }^{199}$ Of course, the activities of the military establishment are such that a court-martial is more likely than

193. U.C.M.J. art. 10, 10 U.S.C. \& 810 (1970).

194. Id. art. 98, 10 U.S.C. $\$ 898$.

195. Court-Martial Processing Standards, U.S. Air Force Judiciary Special Subject Letter No. 37, Nov. 21, 1972. The Air Force guidelines provide that for all courtsmartial only three days should elapse between the accused's being restricted, arrested, or confined by military authorities and the preferring of charges. Id. Delays in excess of these standards must be explained on a chronology sheet for the court-martial.

196. See, e.g., Dickey v. Florida, 398 U.S. 30 (1970) (conviction was vacated for inexcusable and prejudicial delay where more than seven years passed between offense and trial); King v. United States, 265 F.2d 567 (D.C. Cir. 1959) (twenty-week delay with repeated continuances does not violate the right to a speedy trial); People v. Ganci, 27 N.Y.2d 418, 267 N.E.2d 263, 318 N.Y.S.2d 484, cert. denied, 402 U.S. 924 (1971) (trial some sixteen months after indictment does not violate the right to a speedy trial).

197. MANUAL If 53e.

198. See, e.g., United States v. Brown, 7 U.S.C.M.A. 251, 22 C.M.R. 41 (1956).

199. Some of the applicable precedents are cited in United States v. Brown, 7 U.S.C.M.A. 251, 256, 22 C.M.R. 41, 46 (1956). The Task Force Report proposed to extend the right of a public trial to nonjudicial punishment; it recommends that "[a]II Article 15 liearings be open to spectators, except where security interests dictate otherwise, but that the individual have the right to confer privately with the commanders imposing punishment, to relate matters of a personal nature." TASK FoRCe RePort 121. Former Defense Secretary Laird required that "nonjudicial punishment proceedings be opened to the public when requested by an accused except in those instances where military exigencies or security interests preclude public disclosure." Memorandum from Laird, supra note 75. 
a civilian court to have occasion to exclude spectators from a trial in order to avoid disclosure of classified information. Also, because of some resemblances that the article 32 pretrial investigation bears to a grand jury inquiry, the issue has arisen whether such an investigation may be cloaked in the same secrecy which is traditional for grand juries. There is nothing in the Manual for Courts-Martial or in the Uniform Code which clearly indicates that it may not be so held.

\section{Venue}

Both the sixth amendment and article III of the Constitution contemplate that trial shall take place in the state and district where the crime was allegedly committed; and if the offense was not committed within any state, then trial is to be at such place as Congress shall have directed. ${ }^{200}$ In some instances the venue requirement is unclear because of uncertainty about the place where the crime was committed. ${ }^{201}$

Many offenses committed by servicemen take place far outside the United States and so, if tried by a federal district court, would be subject to trial in such place or places as Congress might prescribe. However, with respect to neither offenses committed within nor those committed outside the Umited States has Congress or the President sought to direct where a trial by court-martial should be held. Thus, such trial may occur, and sometimes does occur, quite far from the place where the alleged crime was committed. For example, a serviceman may become absent without leave at one military post and be prosecuted for his absence at some quite different imstallation, where he has returned to military custody. Although it does not recognize the right to a particular venue, the Manual for Courts-Martial does, under very limited conditions amounting to severe prejudice, authorize a motion for change of venue. ${ }^{202}$

\section{Notice to the Accused}

Another sixth amendment right is that of the accused "to be informed of the nature and cause of the accusation." The notice re-

\footnotetext{
200. U.S. CoNST. art. III, $\S 2$; id. amend. VI; 18 U.S.C. $\$ 3237$ (1970); Fed. R. CRIM. P. 18, 20-22.

201. See generally Travis v. United States, 364 U.S. 631 (1961); Johnston v. United States, 351 U.S. 215 (1956); United States v. Johnson, 323 U.S. 273 (1944).

202. The Manual for Courts-Martial provides for change of venue if "the accused demonstrates that there exists at the place of trial where the prosecution is pending so great a general atmosphere of prejudice against him that he cannot obtain a fair and impartial trial in that place ...." Manual $\{69 e$. See generally Chenoweth v. Van Arsdall, 22 U.S.C.M.A. 183, 46 C.M.R. 183 (1973).
} 
quired by the amendment is generally viewed as relating to charges that are being preferred, rather than notice of conduct which is criminal. In view of the form indictinents used in inany jurisdictions, the unwillingness of soine prosecutors to provide bills of particulars, the limitations on criminal discovery, and the secrecy of grand jury proceedings, civilian courts often seein to provide only a bare minimum of notice to an accused of the misconduct with which he is charged. Conversely, military justice provides notable safeguards in this area. The article 32 pretrial investigation required in serious cases-that is, any case referred to a general court-inartial-provides the defendant with detailed knowledge about the charge against him and about the Government's evidence. Furthermore, with limited exceptions for classified information, the statements available to the military prosecutor are made available to the defense as well. ${ }^{203}$

There is also a constitutional requirement, grounded on the due process clauses of the fifth and fourteenth amendinents, that persons be given notice of conduct which is prohibited:204 laws which do not adequately inform citizens of the standards with which they must comply are unconstitutionally vague. ${ }^{205}$ In this regard, military justice receives much lower marks.

Widespread criticism has been heaped upon articles 133 and 134 of the Uniform Code for their vagueness and overbreadth. ${ }^{200}$ Article 133 prohibits "conduct unbecoming an officer and a gentleman."207 Article 134, generally applicable to enlisted personnel and officers, prohibits "all disorders and neglects to the prejudice of good order and discipline in the armed forces" and "all conduct of a nature to bring discredit upon the armed forces." ${ }^{208}$ Criticism of these articles re-

203. Manual I $44 h$.

204. Lambert v. California, 355 U.S. 225 (1957).

205. See, e.g., Papachristou v. Jacksonville, 405 U.S. 156 (1972); Connally v. General Constr. Co., 269 U.S. 385 (1926).

206. See, e.g., O'Callahan v. Parker, 395 U.S. 258, $265-66$ (1969); Everett, Article 134, Uniform Code of Military Justice-A Study in Vagueness, 37 N.C.L. REv. 142 (1959); Gaynor, Prejudicial and Discreditable Military Conduct: A Critical Appraisal of the General Article, 22 HAST. L.J. 259 (1971). But see Wiener, Are the General Military Articles Unconstitutionally Vague? 54 A.B.A.J. 357 (1968).

The 1971 Annual Report of the Court of Military Appeals and the Judge Advocates General proposed that Congress consider legislation to

restrict the scope of Article 134 by enacting separate punitive articles of the code covering selected offenses now dealt with by Article 134, and by limiting the maximum punishment for other conduct prejudicial to good order and discipline or service-discrediting conduct to confinement and forfeitures for 6 months. 1971 ANNUAL REPORT 1, 2.

207. U.C.M.J. art. 133, 10 U.S.C. $\$ 933$ (1970).

208. Id. art. 134, 10 U.S.C. $\$ 934$. 
cently ripened into judicial action in Avrech v. Secretary of the Navy, ${ }^{209}$ where the United States Court of Appeals for the District of Columbia Circuit held article 134 unconstitutionally vague and overbroad on fifth amendment due process grounds. Less than a month after the Avrech decision was handed down, its rationale was reinforced and expanded by the Third Circuit in Levy v. Parker, ${ }^{210}$ where article 133, as well as article 134, was held unconstitutionally vague on its face. In so holding, the court emphasized that the "all-encompassing quality" of the two provisions infused then with a "real capacity for arbitrary and discriminatory enforcennent."211 Read together, the Avrech and Levy decisions strongly remind the Government that "civilian standards of specificity" do apply to the military in defining prohibited conduct. $^{212}$

\section{Discovery}

Related to notice of the accusation against him is the defendant's right to discovery of the Government's case against him. In both federal and state criminal trials, an accused clearly has some constitutional claim to know of certain vital information in the hands of the prosecutor. $^{213}$ Furthermore, in federal trials the accused is entitled to the benefits of the Jencks Act. ${ }^{214}$

Military justice goes far beyond any constitutional rights that might exist in the area of criminal discovery. Generally, the Manual for Courts-Martial requires that trial counsel-the prosecutor-permit the defense to examine "any paper accoinpanying the charges, including the report of investigation . . ." and that he "advise the defense of the probable wituesses to be called by the prosecution ...."215 Furthermore, defense counsel cannot be prevented from interviewing

209. 41 U.S.L.W. 2497 (D.C. Cir. Mar. 20, 1973).

210. 41 U.S.L.W. 2597 (3d Cir. Apr. 18, 1973).

211. Id. With respect to article 133 , which prohibits "conduct unbecoming an officer and a gentleman," the court in Levy observed: "In a society witnessing rapidly changing manners and mores, against what existing standard is gentlemanly conduct to be measured?" Id.

212. Avrech v. Secretary of the Navy, 41 U.S.L.W. 2497, 2498 (D.C. Cir. Mar. 20, 1973).

213. Brady v. Maryland, 373 U.S. 83 (1963); Everett, Discovery in Criminal Cases -In Search of a Standard, 1964 DukE L.J. 477.

214. 18 U.S.C. $\$ 3500$ (1970). The Act, inter alia, allows defendants in federal criminal prosecutions to have access to any statements made by a Government witness relating to the subject matter about which such witness has already testified on direct examination at trial.

215. MANUAL \I $44 h$. 
prospective Government witnesses. ${ }^{216}$ Although the Jencks Act applies to courts-martial, ${ }^{217}$ the broad rules of discovery prescribed by the Manual leave few occasions for invoking the provisions of that Act.

Discovery in criminal cases is sometimes sought by the prosecution; and in such instances the defendant's privilege against self-incrimination may be urged in opposition to granting such discovery. In upholding a Florida requirement that a defendant give notice of an alibi defense as a condition to introducing evidence in support of that defense, the Supreme Court seems to have affirmed the prosecution's right to discovery. ${ }^{218}$ Similarly, the Federal Rules of Criminal Procedure authorize some discovery for the Government.210 Contrariwise, military justice does not currently provide for any discovery on behalf of the prosecution; and there is no requirement that an accused provide notice that he will defend on the basis of alibi, mental irresponsibility at the time of the offense, or lack of mental capacity to stand trial. However, if either the convening authority or the trial counsel foresees that insanity may be a defense, he can arrange for the accused to be evaluated by a sanity board ${ }^{220}$ - through which means the Government may obtain lielpful evidence in resisting the imsanity defense. ${ }^{21}$

\section{Confrontation}

The sixth amendinent provides a criminal defendant with the right to be confronted with the witnesses against him. A landmark precedent affirming the applicability of constitutional rights to military personnel held that a deposition could not be received in evidence over the objection of an accused who had not been allowed an opportunity to be present when the deposition was taken. ${ }^{222}$ However, the Government still may use at trial the deposition of a witness who has become unavailable, if the accused and his counsel were present when the deposition was taken. Furthermore, courts-martial, like civilian courts, are allowed to receive the former testimony of an absent witness given at a prior trial of the accused " $\mathrm{m}$ which the issues were substantially the

216. Id. Iा $42 c$, $44 h$.

217. United States v. Albo, 22 U.S.C.M.A. 30, 46 C.M.R. 30 (1972).

218. See Williams v. Florida, 399 U.S. 78 (1970).

219. FED. R. CRIM. P. 16(c). The Government's right to discovery is conditioned upon discovery's being granted to the defendant under Rule 16; thus, to avoid discovery by the Government, the defendant may be forced to relinquish his own right of discovery.

220. Manual II 121.

221. See, e.g., United States v. Babbidge, 18 U.S.C.M.A. 327, 40 C.M.R. 39 (1969).

222. United States v. Jacoby, 11 U.S.C.M.A. 428, 29 C.M.R. 244 (1960). 
same."223 In such instances, there is preserved not only the opportunity for cross-examination-which probably is the core of the right of confrontation-but also the presence of the accused when the witness gives his testimony.

Like the right of confrontation, the common law hearsay rule enbodies a policy against receiving in evidence the statements of a person who is not present in court for cross-examination. Of course, the hearsay rule can work to exclude defense evidence as well as that offered by the prosecution, while the constitutional right of confrontation belongs solely to the defendant. The Manual for Courts-Martial applies the hearsay prohibition to courts-martial and also recognizes various exceptions thereto-many of them familiar to civilian jurisprudence. ${ }^{24}$ These exceptions often have the practical effect of diminishing the scope of the right of confrontation.

Of special importance to courts-martial are the hearsay exceptions for official records ${ }^{225}$ and busmess entries. ${ }^{226}$ Indeed, because of these exceptions the Government evidence in some cases-especially those involving unauthorized absence or desertion-is exclusively or chiefly documentary. Furthermore, since the military establishment prescribes the rules which govern the preparation of official records and the information to be contained therein, military authorities to some extent may determine the scope of the official records exception to the hearsay rule-and thus may, in effect, limit the right of confrontation. 227

Generally speaking, however, the military rules of evidence tend to adhere to the civilian model, and existing disparities are not crucial.

223. Manual $\int 145 b$. The Organized Crime Control Act of 1970 now makes express provision for the taking of depositions to preserve testimony and for the use of the deposition at trial by either party if the witness is unavailable or refuses to testify concerning the subject of the deposition. 18 U.S.C. $\$ 3503$ (1970).

224. MaNUal Tfi 139 (general rule), 140-46 (exceptions).

225. Id. I 144b. Admissibility of an official record of a fact or event depends on the existence of an official duty to record that fact or event. See, e.g., United States v. Kitchen, 5 U.S.C.M.A. 541, 18 C.M.R. 165 (1955); United States v. Bennett, 4 U.S.C.M.A. 309, 15 C.M.R. 309 (1954); United States v. Wilson, 4 U.S.C.M.A. 3, 15 C.M.R. 3 (1954).

226. Manual If $144 c$.

227. See, e.g., United States v. Simone, 6 U.S.C.M.A. 146, 19 C.M.R. 272 (1955); United States v. Kitchen, 5 U.S.C.M.A. 541, 18 C.M.R. 165 (1955), where by a change in record-keeping requirements the Government was able to eliminate certain problems of proof in desertion cases. In United States v. Wilson, 4 U.S.C.M.A. 3, 15 C.M.R. 3 (1954), the Government's case hinged on certain delayed entries which had been made in official records nuany months after the events which they recited; but the court concluded that the entries had been made pursuant to an official duty and therefore wore admissible. 
For example, in military justice, as in most civilian courts, a memorandum which is properly shown by a witness to embody his past recollection recorded is admissible as substantive evidence. ${ }^{228}$ On the other hand, a prior inconsistent statement is admissible in a military trial for impeaching purposes but not as substantive evidence of the fact that it asserts. $^{229}$ The Proposed Federal Rules of Evidence, however, would allow the prior inconsistent statement in as substantive evidence. ${ }^{230}$

\section{Obtaining Witnesses}

In civilian courts an accused is entitled "to have compulsory process for obtaining witnesses in his favor."231 Article 46 of the Uniform Code provides that process issued in court-martial cases shall be similar to that which the federal district courts may issue and shall run to any part of the United States. ${ }^{232}$ Thus, unlike the process of a state court, the subpoena issued to a witness to appear and testify before a court-martial is not limited by state boundaries.

A federal grand jury may subpoena witnesses to appear before it; but the language of articles 46 and 47 of the Uniform Code, which punish refusal to appear or testify, ${ }^{233}$ suggests strongly that compulsory process is not available for the defense or the Government during the pretrial investigation. On the other hand, the Code does authorize compulsory process to compel an appearance for the taking of a deposition. ${ }^{234}$

Many offenses under the Uniform Code will occur and be tried outside the United States. In such instances, the appearance of mil-

228. MaNual I 146a. The proposed Federal Rules of Evidence also allow the admission in evidence of past recollection recorded as an exception to the henrsay rule. Proposed Federal Rule of Evidence 803(5).

229. MANual $\int 153 b(2)(c)$.

230. Proposed Federal Rule of Evidence $801(d)(1)$. The constitutionality of this view has been upheld in California v. Green, 399 U.S. 149 (1970), over the objection that the defendant's right of confrontation had been violated.

231. U.S. CoNsT. amend. VI.

232. U.C.M.J. art. 46,10 U.S.C. \& 846 (1970).

233. Id. arts. $46-47,10$ U.S.C. $\$ \S 846-47$. In its reference to the trial counsel, the defense counsel, and the court-martial, article 46 seems to contemplate charges that have already been referred for trial by court-martial-an event that would be subsequent to any pretrial imvestigation nnder article 32 . Article 47 refers to a person subpoenaed "to appear as a witness before a court-martial, military commission, court of inquiry, or any other military court or board, or before any military or civil officer designated to take a deposition to be read in evidence before such a court, commission, or board . ..."Id. art. 47(a)(1), 10 U.S.C. $\$ 847$ (a)(1). There is a conspicuous omission of any reference to an officer conducting a pretrial investigation.

234. See id. art. 47,10 U.S.C. $\$ 847$. 
itary witnesses can be obtained by means of military orders. However, court process will not be available to compel the appearance of foreign civilian witnesses in behalf of either the Government or the defense, but the attendance of such witnesses may sometimes be obtained through the aid of an appropriate foreign government. ${ }^{235}$

In the event of disagreement between trial counsel and defense counsel as to whether a witness' testimony is necessary, the matter is referred to the convening authority or, if trial has begun, to the military judge. ${ }^{238}$ In such cases, the defense counsel must provide a synopsis of the witness' expected testimony and state why the witness' personal appearance is necessary. ${ }^{237}$ Through the information required to support a defense request for a subpoena, the Government receives some discovery of the defense's case. However, under prevailing doctrine, such discovery does not appear to involve an unconstitutional abridgment of the defendant's privilege against self-incrimination. ${ }^{238}$ Moreover, without some requirement that the defendant state his grounds for requesting issuance of subpoenas, the requests for subpoenas might become frivolous. Where a request for a subpoena has been properly presented and improperly denied, the Court of Military Appeals has not been reluctant to reverse an ensuing conviction. ${ }^{239}$

\section{Right to Bail}

Although the eighth ainendment provides that "[e]xcessive bail shall not be required," military justice has never recognized bail as a means for obtaining release from pretrial or post-trial confinement. However, this absence of bail seems less important in practice than it might seem in theory. In this respect, it should be initially noted that the bail system has proven less than satisfactory in the civilian courts; many abuses, for imstance, have been associated with the activities of bail bondsmen. Accordingly, Congress passed the Bail Reform Act of $1966,{ }^{240}$ which has provided various alternatives to bail; some states have followed suit. Secondly, the Uniform Code prohibits indiscriminate use of pretrial confinement for minor offenses, ${ }^{241}$ and the

235. See Manual đf $115 d(1)$; J. SNee \& A. Pye, supra note 77, at 94-101.

236. Manual II $115 a$.

237. Id.

238. Cf. Williams v. Florida, 399 U.S. 78 (1970).

239. See Everett, The Role of the Deposition in Military Justice, 7 MIITARY L. REv. 131, 137-38 (1960).

240. Act of June 22, 1966, Pub. L. No. 89-465, 80 Stat. 214, amending 18 U.S.C. $\S 3146$ (1964) (codified at 18 U.S.C. $\$ \$ 3146-52$ (1970)).

241. The Uniform Code provides that an accused "shall be ordered into arrest or confinement, as circumstances may require; but when charged only with an offense 
violation of this mandate may itself constitute an offense under the Code. $^{242}$ Moreover, various military commands have issued directives intended to diminish pretrial confinement, and confinement imposed in violation of these directives is also illegal. ${ }^{243}$ Third, the emphasis in military justice on speedy trial ${ }^{244}$ reduces some of the baneful effects of pretrial confinement. ${ }^{245}$ Fourth, the accused serviceman in pretrial confinement is apparently still in a pay status, ${ }^{240}$ while his civilian counterpart who awaits trial in a jail often will lose his job and source of income while trial is pending. Fifth, post-conviction service of a sentence to confimement may be deferred in the discretion of the convening authority. ${ }^{247}$ And sixth, the Court of Military Appeals has recently recognized a broad new remedy allowing servicemen to contest improper pretrial or post-trial confinement. ${ }^{248}$ Additionally, the Army's recent program creating "military magistrates," who have authority to release from pretrial confinement, is additional evidence of the military's desire to reduce pretrial confimement to the barest mim-

normally tried by summary court-martial, he shall not ordinarily be placed in confineinent." U.C.M.J. art. 10, 10 U.S.C. $\$ 810$ (1970). Article 13, which prohibits pretrial punishment, directs that arrest or confinement prior to trial shall not be "any more rigorous than the circumstances require to insure his presence." Id. art. 13, 10 U.S.C. $\& 813$. Thus, it seems to parallel the strong intimation in Stack v. Boyle, 342 U.S. 1 (1951), that the only permissible purpose of pretrial confinement is to assure the defendant's presence for trial. The Manual for Courts-Martial may go further than this when it authorizes pretrial confinement if "deemed necessary to insure the presence of the accused at the trial or because of the seriousness of the offense charged." MaNual I 20c. However, this is still short of preventive detention. Cf. D.C. CoDe ANN. \$§ 23-1321 to -1332 (Supp. IV, 1971).

242. U.C.M.J. art. $98(2), 10$ U.S.C. \& $898(2)$ (1970).

243. See United States v. Gray, 6 U.S.C.M.A. 615, 620, 20 C.M.R. 331, 336 (1956). See also 1962 Hearings 847, 873, 908-09, 925, 944, 961.

244. See notes 191-96 supra and accoinpanying text.

245. In civitian life, a defendant who undergoes lengthy pretrial confineinent may be rendered destitute.

246. Under article 57 (a), 10 U.S.C. $\$ 857$ (a) (1970), forfeitures may apply only to pay and allowances that becoine due on or after the date the sentence is approved by the convening authority. No forfeiture may apply to pay or allowances accrued before that date.

247. Id. art. 57(d), 10 U.S.C. $\$ 857$ (d). If the accused is no longer under the command of the convening authority, service of the sentence to confinement may be deferred by the officer exercising general court-martial jurisdiction over the command to which the accused is currently assigned.

248. Article 138, 10 U.S.C. $\$ 938$ (complaints of wrongs), is now deemed by the court to be a proper remedy for contesting illegal pretrial or post-trial confinement. Dale v. Umited States, 19 U.S.C.M.A. 254, 41 C.M.R. 254 (1970); Walker v. United States, 19 U.S.C.M.A. 247, 41 C.M.R. 247 (1970). Except as to confineinent, the armed services apparently believe that article 138 does not apply to matters involving discipline. See Judge Advocate General, Air Force, Opinion 1972/111 (Oct. 17, 1972); Judge Advocate General, Air Force, Opinion 1972/53 (Apr. 26, 1972). 
imum. ${ }^{249}$ In view of the frequent accounts of difficulties in the civilian system in the administration of bail, military justice, in practice, seems to offer very adequate substitutes for bail.

\section{Cruel and Unusual Punishment}

In addition to providing a right to bail, the eighth amendment prohibits excessive fimes and the infliction of cruel and unusual punishments. The restrictions on fines imposed by the Manual for CourtsMartial make them a seldom-used punishment in military justice and leave little room for them to be excessive. ${ }^{250}$ The Manual also directs courts-martial to consider the "ability of the accused to pay" in determining the amount of forfeitures of pay as well as fimes. ${ }^{251}$

The Uniform Code contains an express prohibition of cruel or unusual punishments, including some specific punishments that were at one time used by courts-martial and military commissions. ${ }^{252}$ In United States $v$. Wappler, this statutory prohibition was lield by the Court of Military Appeals to embrace punishments that might not fall withm the purview of the eighth amendinent. ${ }^{253}$ Reading the Uniform Code as a whole, the court concluded that Congress imtended to prohibit as cruel and unusual punishment confinement on bread and water for more than three days and that even the three-day punishment was limited to those servicemen "attached to or embarked in a vessel."254 It is doubtful that all civilian courts would infer such broad protection from the cruel and unusual punishment clause.

Capital punishment traditionally has been part of military justice. Presumably, a clear decision that capital punishment is cruel and unusual would be applied to courts-martial. However, the Supreme Court's recent ruling in Furman v. Georgi $a^{255}$ seems to bar only the arbitrary imposition of capital punishment at a jury's unguided discretion. In the Uniform Code, capital punishment is mandatory only for spies. ${ }^{256}$

249. See note 71 supra and accompanying text.

250. According to the Manual for Courts-Martial, "[a] fine normally should not be adjudged against a member of the armed forces unless the accused was unjustly enriched as the result of the offense of which he is convicted." MaNual If $126 h(3)$. Moreover, "[s]pecial and summary courts-inartial may not adjudge any fine in excess of the total amount of forfeitures which may be adjudged in a case." Id.

251. Id. ๆ $126 h(1)$.

252. U.C.M.J. art. 55, 10 U.S.C. $\$ 855$ (1970). This article prohibits branding, marking, or tattooing on the body, flogging, and the "use of irons, single or double, except for the purpose of safe custody . . .."

253. 2 U.S.C.M.A. 393, 9 C.M.R. 23 (1953).

254. Id. at 396, 9 C.M.R. at 26.

255. 408 U.S. 238 (1972).

256. See U.C.M.J. art. 106, 10 U.S.C. $\$ 906$ (1970). 
For the other offenses where it is authorized by the Code, capital punishment is only a permissible punishment. ${ }^{257}$ Accordingly, for those offenses the power to impose capital punishment seems in doubt-on the premise, of course, that, where not excluded by the exigencies of the service, constitutional rights do apply to military personnel.

\section{Appellate Review}

In civilian courts the existence of important rights is sometimes jeopardized by the difficulties and costs of vindicating those rights on appeal. For example, access to a free transcript of the trial ${ }^{258}$ and provision of cost-free counsel for a first appeal as of right ${ }^{250}$ are predicated on a demonstration of indigency. Consequently, convicted civilians of limited means, if above the "indigency" level, may be forced by economic considerations to forgo the appellate process, especially if the conviction is for a relatively minor offense. In view of these considerations, a civilian prosecutor or trial judge may take legally questionable action secure in the knowledge that the action will never be reviewed on appeal.

The corresponding military procedures seein less vulnerable to such abuse. Initially, military justice provides a verbatim record of trial to an accused without any showing of indigency on his part. ${ }^{200}$ Since review of certain sentences is automatic, the availability of the trial record does not depend on the accused's filing a notice of appeal or otherwise deinonstrating his intention to appeal. More significantly, military appellate defense counsel can be used by an accused without cost and without any requirement of a demonstration of indigency. The accused is free, of course, to retain civilian counsel to aid in his appeal at his own expense.

Military justice provides several levels of broad appellate review. The convening authority provides the mitial review of the law, facts, and sentence, and possesses an absolute discretion to grant clemency to the accused. ${ }^{261}$ In any case where there is a punitive discharge or confinement for a year or inore, a Court of Military Review must also review the facts, law, and appropriateness of the sentence. ${ }^{262}$ Review by

257. E.g., id. arts. 94 (mutiny or sedition), 99 (misbehavior before the enemy), 104 (aiding the enemy), 10 U.S.C. $\$ \$ 894,899,904$ (1970).

258. Griffin v. Illinois, 351 U.S. 12 (1956).

259. Douglas v. California, 372 U.S. 353 (1963).

260. U.C.M.J. arts. 19, 54, 10 U.S.C. $\$ \S 819,854$ (1970).

261. Id. arts. $60-64,10$ U.S.C. $\S \S 860-64 ;$ see, e.g., United States v. Massey, 5 U.S.C.M.A. 514, 18 C.M.R. 138 (1955).

262. U.C.M.J. art. 66, 10 U.S.C. $\$ 866$ (1970). This review is on the entire record 
the Court of Military Appeals is limited to questions of law. Compulsory review of the facts and appropriateness of sentence, virtually unknown in the civilian setting, constitutes a unique feature of military justice. $^{203}$ Finally, additional extraordinary remedies are available to an accused serviceman in contesting his conviction and sentence where alleged violation of constitutional rights is involved. ${ }^{204}$

\section{Pending Proposals for Reform}

Article 67(g) of the Uniform Code requires that the judges of the Court of Military Appeals, the Judge Advocates General of the armed forces, and the General Counsel of the Department of Transportation meet annually to survey the operations of the Code and report thereon to the congressional Committees on Armed Services, the Secretary of Defense, and the secretaries of the military departments. ${ }^{265}$ In its report for 1971, this Code Committee made legislative reeommendations that Congress (1) clarify the authority of military judges, Courts of Military Review, and the Court of Military Appeals to grant extraordinary relief; (2) permit earlier execution of a sentence to confmement; (3) remove the convening authority's responsibility to make a post-trial review of the court-martial's findings; and (4) restrict the scope of article 134 of the Code. ${ }^{268}$ The Code Committee will continue to consider other proposals-of which the most significant would probably be granting the military judge sentencing power in all cases not involving a death penalty, establishing a system of random selection for court-martial members, and permitting an appeal directly from the Court of Military Appeals to the Supreme Court.

Senator Bayh has advocated legislation that would take from military commanders many of the responsibilities that they have tradition-

of trial, and this record must be verbatim. Id. arts. 66(b), (c), 10 U.S.C. $\$ \S 866(\mathrm{~b})$, (c); MaNuAL ITा 82,83 .

263. The Task Force Report recommends these changes in appellate review: in other than capital cases, automatic review of all general courts-inartial and special courts-martial in which a bad conduct discharge is approved by the convening authority should be eliminated, except for a clemency review by the convening authority; instead, the appellate judiciary should review only those cases appealed by the accused; the accused should have the right to appeal in all special courts-martial; and a verbatim record of trial should be prepared in those cases in which the accused indicates an appeal will be made. TASR FORCE REPORT 125-26. Apparently the Task Force concluded that the automatic appeal now provided by the Code in serious cases is not worth the effort, expense, and delay but that for inany minor offenses the appellate review should be expanded.

264. See note 68 supra and accompanying text.

265. U.C.M.J. art. $67(\mathrm{~g}), 10$ U.S.C. $\& 867(\mathrm{~g})(1970)$. The Secretary of Transportation has authority over the Coast Guard.

266. 1971 ANNUAL REPORT 2. 
ally exercised in appointing court-martial personnel and referring cases to courts-martial for trial. ${ }^{267}$ Also, the Senator would eliminate the summary court-martial, transfer sentencing responsibilities to military judges, authorize random selection for court-martial membership, and broaden the base of court membership. Appellate review would be altered and provision made for appeal from the Court of Military Appeals to the Supreme Court by petitions for certiorari. To screen cases before trial and reduce pretrial confinement, provision would be made for an initial appearance and preliminary examination like that authorized under Rule 5 of the Federal Rules of Crimmal Procedure. $^{268}$ Senator Bayh would also provide a statutory basis for an expanded right of discovery in military cases and would authorize military defense counsel to seek collateral relief in civil courts.

A proposal by Senator Hatfield would limit military jurisdiction to certain military offenses and transfer jurisdiction over many other offenses to the federal district courts. ${ }^{200}$ The Hatfield proposal would also provide for random selection of court members and would alter the rules for determining the composition of the courts. ${ }^{270}$

The Report of the Task Force on the Administration of Military $J_{u s t i c e^{271}}$ has recommended a broad array of reforms, many of them in response to complaints of racial discrimination within the system of military justice. The scope of these recominendations is too broad to catalogue within the confines of this Article, but it should be noted that they have already resulted in affirmative action by the Secretary of Defense. In response to the Task Force recommendations, the Secretary has already ordered significant reform of nonjudicial punisliment procedures, as well as the initiation of affirmative action towards isolating defense counsel inore fully from command influence. ${ }^{272}$

While the Task Force's recommendations are wide-ranging and, in many respects, significant, they are less than revolutionary. ${ }^{273}$ Consequently, their implementation may help the armed services to forestall more sweeping changes should military officials be so inclined.

267. Bayh, supra note 10.

268. FED. R. CRIM. P. 5.

269. S. 4178 , 91st Cong., $2 \mathrm{~d}$ Sess. $\S 821$ (1970), reprinted in 116 Cong. Rec. 27, 223 (1970); see Sherman, supra note 10, at 29.

270. S. 4169 , 91st Cong., 2d Sess. $\$ 825$ (1970), reprinted in 116 Cono. Rec. 27, 220-21 (1970); see Sherman, supra note 10, at 44-46.

271. See note 74 supra and accompanying text.

272. See note 75 supra and accompanying text.

273. See TASK FORCE REPORT 112-27, succinctly stating the specific recommendations of the Task Force. 


\section{CONCLUSTONS}

As a result of the Military Justice Act of 1968, the decisions of the Court of Military Appeals, and such precedent-shattering cases as $O^{\prime}$ Callahan, Avrech, and Levy ${ }^{274}$ military justice has taken on a new look. Even so, there are still cries for further changes. The armed services plead, however, that the existing system be given a chance to work before further major legislative changes are made. In justifying their position, the services point to their own demonstrated willingness to undertake innovations in the administration of military justice and to existing procedural safeguards, which compare favorably with those available in many civilian courts.

One suspects that these arguments will be sufficient to prevent major legislative changes. However, it is likely that the role of military judges will be expanded in various ways-for example, by granting them sentencing power even in cases where the issues of fact are tried by the military jury, ${ }^{275}$ by permitting them to suspend sentences or defer confmement, by authorizing thein to issue "search warrants" and to rule on the need for pretrial confinement, and by empowering them to issue extraordmary relief. Also, the summary court-martial should soon virtually disappear from the scene. Already the absolute right of an accused to object to the jurisdiction of this court-1nartial and the probable applicability of the Argersinger $v$. Hamlin ${ }^{276}$ requirement of counsel have significantly reduced its utility as an expeditious and simplified tribunal. Moreover, the availability of trial before a military judge in a special court-martial, as opposed to trial before a nonlegal officer in the summary procedure, might render the former more desirable in some cases even from the standpoimt of the accused. The cases that have been handled by summary courts-martial should be susceptible to disposition by special courts-martial-especially if there is a decline in the overall court-martial rate and if trial by military jury continues to be waived in a substantial percentage of cases.

Since disposition of the minor offenses is subject to the fewest procedural safegnards in both civil courts and military justice, ${ }^{277}$ there will probably be increased attention to the procedures used for handling such offenses. Thus, nonjudicial punishment under article 15 will be closely supervised by the armed services to prevent discrimination or

274. See notes 49-59, 209-12 supra and accompanying text.

275. This sentencing power for military judges has been recommended by the Task Force. TASK ForCe REPORT 124.

276. 407 U.S. 25 (1972). See notes $152-54$ supra and accompanying text.

277. Petty offenses are not subject to the constitutional requirements of jury trial or grand jury indictment. See notes 51-55 supra and accompanying text. 
arbitrariness in its imposition. ${ }^{278}$ However, in this area new legislation does not seein necessary and solutions to problems should be attainable through administrative action by the services themselves or by the Department of Defense-such as the Laird Memorandum's insistence on the provision of "adequate legal advice" to the accused before imposition of nonjudicial punishment. Moreover, the accused's right to object to nonjudicial punishment provides him with a valuable shield against unfair treatment. ${ }^{279}$

Plea-bargaining, a inuch criticized but important feature of military justice in the Army, Navy, and Marine Corps, ${ }^{280}$ has received approval froin the Supreme Court in the civilian setting. ${ }^{281}$ Therefore, no coinpelling reason exists for its abandonment by the military-especially if the armed services continue to undergo a shortage of experienced military lawyers.

The selection of court-martial members by the convening authority will remain a sore spot. However, this issue should become less in1portant if there continues to be extensive waiver of trial by military jury and if the military judges are granted sentencing power even in cases where guilt is determined by the court-martial inembers. Randoin selection of court-martial meinbers has apparently been undertaken on a limited basis in the field ${ }^{282}$ _although its legality is not completely clear under the Code's present wording. ${ }^{283}$ However, regardless of the method of selection of court members, there probably will continue to be claims that, in some way, their rank and relationship to military commanders influenced their decisions. The high incidence of waiver of trial by full court-inartial in favor of trial by mili-

278. See TASK FORCE REPORT 120-21; Memorandum from Laird, supra note 75. 279. This right exists unless the defendant is attached to or embarked in a vessel. U.C.M.J. art. 15 (a), 10 U.S.C. $\$ 815$ (a) (1970). This exception, apparently designed to meet the needs of the Navy, retained for a ship's captain the authority to place a man in the brig without going through a court-martial. Id. art. $15(\mathrm{~b})(2)(\mathrm{A}), 10$ U.S.C. $\S 815(b)(2)(A)$. Since many naval vessels do not have qualified legal personnel assigned to them, it is difficult to imagine how such seagoing commands can possibly comply with the Secretary of Defense's directive for the provisiou of "adequate legal advice" prior to the imposition of nonjudicial punishment or with the recent district court decisions requiring the availability of counsel in summary courts-martial.

280. The Air Force has continued to frown ou plea-bargaining. See note 72 supra.

281. See Santobello v. New York, 404 U.S. 257 (1971).

282. See Reincho, supra note 164 , at 199.

283. See U.C.M.J. art. 25 (d)(2), 10 U.S.C. $\$ 825$ (d)(2) (1970), which seems to imply that the commander should exercise personal discretion in selecting court-martial members. But cf. United States v. Keinp, 22 U.S.C.M.A. 152, 46 C.M.R. 152 (1973). See notes 166-67 supra and accompanying text. Random selection seems to be at the other pole from conscious selection of the best qualified persons to serve on the court. 
tary judge seems to testify to the pervasiveness of this feeling among military personnel. In that respect, military judges, insulated from the control of commanders in the field and strengthened in their independence and objectivity by the judicial ethic, do seem relatively immune from command influence. Thus, their emergence on the military justice scene may provide an answer to a persistent complaint.

Finally, the relative success of military justice in avoiding court congestion and trial delays constitutes an additional impressive argument against further precipitous changes. Certainly proposals to change military justice should carry a burden of proof that they will not materially delay military criminal law administration.

While the new look in military justice does not constitute utopia, ${ }^{284}$ the most compelling needs for change seem already to have been rmet.

284. It should be noted that the advent of an all-volunteer army may lead to certain attitudinal changes in military justice. Perhaps the armed services will be under considerable pressure to continue improvement of military justice so that it will not be an obstacle to securing enlistments. On the other hand, the courts may become less protective of an enlistee who has voluntarily subjected himself to military justice than with respect to inductees who have become part of the military establishment against their wills. Finally the all-volunteer service may have an entirely different courtmartial rate than that of a military establishment based in part on conscription. For example, there may be greater selectivity, with the result being a drop in the courtmartial rate and the number of offenses. On the other hand, the all-volunteer army may produce an ethnic and economic mix in the armed services which is conducive to greater tension and disorders. 


$$
\text { . }
$$

